\title{
Fuzzy Model for Diagnosing Soft Skills in Engineering Training
}

\author{
Débora Barni de Campos ${ }^{1 *}$, Luis Mauricio Martins Resende ${ }^{2}$, Alexandre Borges Fagundes ${ }^{1}$ \\ ${ }^{1}$ Departamento de Tecnologia Industrial, Centro de Educação do Planalto Norte, Universidade do Estado de Santa Catarina, \\ São Bento do Sul, Brasil \\ ${ }^{2}$ Departamento de Engenharia de Produção, Campus de Ponta Grossa, Universidade Tecnológica Federal do Paraná, \\ Ponta Grossa, Brasil \\ Email: *deborabarni@gmail.com
}

How to cite this paper: de Campos, D. B., Resende, L. M. M., \& Fagundes, A. B. (2020). Fuzzy Model for Diagnosing Soft Skills in Engineering Training. Creative Education, $11,2672-2721$.

https://doi.org/10.4236/ce.2020.1112198

Received: September 25, 2020

Accepted: December 14, 2020

Published: December 17, 2020

Copyright (c) 2020 by author(s) and Scientific Research Publishing Inc. This work is licensed under the Creative Commons Attribution International License (CC BY 4.0).

http://creativecommons.org/licenses/by/4.0/

\section{(c) (i) Open Access}

\begin{abstract}
This work presents the development of a model based on fuzzy logic to perform an evaluation and decision making based on multiple criteria intended to diagnose soft skills in Engineering courses. This scientific tool was developed using the fuzzyTECH software, which supported the calculations necessary for the delivery of the results. The hierarchical structure of the top-down tree was developed using a Systematic Bibliographic Review, based on the search databases Web of Science, Science Direct, Scopus databases and on the European Journal of Engineering Education and Journal of Engineering Education. The search comprised 15 years and combined keywords from two main fields: Engineering and Humanities. The 3951 articles obtained were ranked by the scientific ranking algorithm indexOrdinatio, which takes into account the year of the article search, the year of publication, the number of citations in Google Scholar and the JCR of the journal in which the article is indexed. At the end, 59 articles were critically analyzed, capturing the most important soft skills for Engineers to be used in the modeling composition. This robust tool has been validated and has shown the characteristics of reliability, stability, validity and consistency.
\end{abstract}

\section{Keywords}

Fuzzy Logic, FuzzyTECH ${ }^{\oplus}$, Systematic Bibliographic Review (SBR), Index Ordinatio, Soft Skills for Engineering

\section{Introduction}

The authors of this study, as professors of Engineering courses, realize that often, the construction of pedagogical projects is carried out based on ruled deci- 
sions without an empirical analysis, possibly due to the high complexity of the areas within the soft skills.

In the development of these pedagogical projects, it is not common to use tools that comprise soft skills in the training of engineering professionals. There is also not a wide range of instruments that assist the decision-making process in Engineering training regarding soft skills.

The choice of fuzzy logic to conceive the modeling presented in this work was motivated by the fact that it operates in a similar way to human reasoning, incorporating subjectivities intrinsic to soft skills.

There are still few tools to assist in the decision making process regarding soft skills assessment in the training of Engineers. This fuzzy modeling allows identifying strengths and weaknesses in the development of soft skills in Engineering courses, promoting measurable and specific adjustments in Engineering curricula.

Therefore, this study aims to provide a scientific modeling that supports the need to evaluate multifactorial elements, based on fuzzy logic. This model allows that the perceptions of students, professors, graduates, and Engineering contractors are considered for the development of pedagogical projects in the Engineering area. It also measures the perceptions of the Engineer contractors about the reality seen in the job market.

\section{Theoretical Reference}

\subsection{Fuzzy Logic}

According to Martins and Martins (2016) and Cavalcanti et al. (2013), it was Aristotle (384 - 322 BC), a Greek philosopher and the founder of the Logic Science, who instituted strict rules to accept premises as logically valid. From this starting point, values were attributed to the statements, considering them as true or false. It was the beginning of Boolean logic, later named binary.

Campos Filho (2004) states that Boole, in 1847, in his book "The Mathematical Analysis of Logic", applied numerical values for the statements, with 1 (one) being the true premises, and 0 (zero) being the false premises. For Sousa and Boente (2016), since then logical thinking has been conditioned to binary logic, in which a sentence is true or false, not admitting to be partially true or partially false.

Fuzzy logic had its origin in 1903, when Bertrand Russell discovered an ancient Greek paradox, known as "Russell's paradox", which, when solved by Aristotelian logic, always led to contradictions. It was the fuzzy logic, which accepts partial situations, which could solve the problem. In the mid-1930s, the Polish Jan Lukasiewicz made the first multilevel essays, in which he stated that contradictions were perfectly plausible from a mathematical point of view, as long as the degrees of truth were not bivalent. The Polish scholar incorporated the fraction of logical states between 0 (zero) and 1 (one) into the logic (Campos Filho, 2004; Brayan \& Brayan, 1997). 
But it was in the 60s that the fuzzy logic was mathematically equated and tested by Zadeh, a professor at the University of Berkeley (California-USA), who was unsatisfied with the technological resources available for the automation demands of the time. Zadeh realized that some industrial sectors, such as Biological and Chemical, were (and still are) susceptible to ambiguous occurrences that could not be fulfilled by the $1 \& 0$ values of the binary (Boolean) logic (Cavalcanti et al., 2013).

Fuzzy logic followed the traditional course of technological innovations: born in the United States, perfected in Europe and widespread in Japan. In the 1980s, fuzzy logic was used especially in Europe to support decision making and was applied to information analysis on research about human decisions process (Campos Filho, 2004). According to Toledo \& Cosenza (2004), some industrial processes involve the human reasoning and it is safer to use of a tool that efficiently substitutes human in decision making. Still in the 1980s, according to Campos Filho (2004), companies in Europe found that the Japanese made it feasible to use the fuzzy logic in control technologies, and expanded the efforts to promote this logic in their applications.

\subsubsection{Fuzzy-Rule Blocks}

Rule blocks are "if-then" tables containing the strategic control of the fuzzy system (Fagundes, 2015). In these blocks, all the rules for the same context are grouped, as exemplified in Figure 1, for the index "Active Listening". This, in turn, is defined with the same rules as the input indicators, referred in this study by the term "guidelines", and the output, referred within this work as "indicators", "indexes" and "final index".

To compose the rule block, operations are carried out using fuzzy logic, generating a set of relevant results, in pre-defined thematic groups (Campos Filho, 2004). The values are following transported to the composition of other groups, until the definition of the final index, which in the present work is the diagnosis of soft skills development in Engineering training.

The production rule blocks contain the strategic control of the fuzzy system. Each of them combines all the rules into the same context. A context is defined by the same rules of the input (individual or thematic) and the output (thematic or systemic) indicators. Each rule block composition operation generates a set of results in pre-defined fields, according to fuzzy logic.

The sequence of operations transforms and carries values until the definition of the systemic indicator. The various thematic indicators can also be verified on scales of predefined reference fields, in the same way as the systemic indicator. Degree of Support (DoS) is used to assign a weight to each of the rules. These weights vary between 0 (zero) and 10 (ten) and are assigned according to the importance of these rules in the understanding of the specialist and decision makers-in this work represented by the organizational psychologists. The values assigned for the degrees of support of each of the rules for the model developed are specified in Table 7, shown in Section 4. 


\subsubsection{Dendogram}

The fuzzy model developed to diagnose the development of soft skills in Engineering training, combines, orders and details the most important soft skills for Engineers with their respective thematic indicators and individual guidelines. According to Campos Filho (2004), the guidelines and indicators take diffuse forms and are aggregated into the rule blocks of the main Dendrogram, Top Down Induction of Decision Trees, by means of fuzzy set operations.

The complete Dendrogram used for making the fuzzy modeling, specifically developed for this work, is described and illustrated in the Methodology 3 of this research.

In this Top-Down fuzzy tree, the result, which is the diagnosis of soft skills development in Engineering training, is obtained according to the tree analogy, opening up in new "branches" until reaching information that can be sought, data that can be analyzed. The end of new branches-or "tree layers"-creation occurs at the moment the researcher gets the facts and information needed.

\subsubsection{The FuzzyTECH Software}

The FuzzyTECH Software is a tool developed to use of fuzzy logic, with a graphical interface for the illustration of its components. It has features for editing rules, which can be explained in matrix form or in spreadsheet form. It also allows the analysis of each stage of the system in operation, through the construction of graphics in both 2D or 3D formats (Arruda et al., 2013).

Still according to the authors, the tool was developed by INFORM, in 1987, with the intention of domestic use and it was later shared with the European market. The available features include maximum and minimum operators for aggregating the input data for each rule, editing with analysis of various relevant functions and many methods for defuzzyfication-including the high center and the area center. It also generates the documentation of the project is being executed, including graphics and rule blocks.

The choice to use fuzzyTECH to build the model to diagnose the development of soft skills in Engineering training was due to some reasons: friendly interface, non-requirement of specific programming knowledge, worldwide support and use (e.g. Berlin airport, for air traffic control) and finally, because the authors of this study acquired the version 5.54 license.

As this study is related to the Human Sciences, the variables involved are not binary variables, such as "yes" or "no", "right" or "wrong", "true" or "false", but rather variables that resemble human thought, which involves ambiguity, imprecision and belonging to different situations at the same time.

Finally, with the intention of diagnosing the development of soft skills in Engineering training, the use of a logical and mathematical treatment of the data was used. These were obtained through verbal information of imprecise and vague impressions, as well as subjective quality. For this purpose, the fuzzy logic was used, as this tool manages to treat variables in a rational manner; for being based on human reasoning modeling and not restricted to values. 


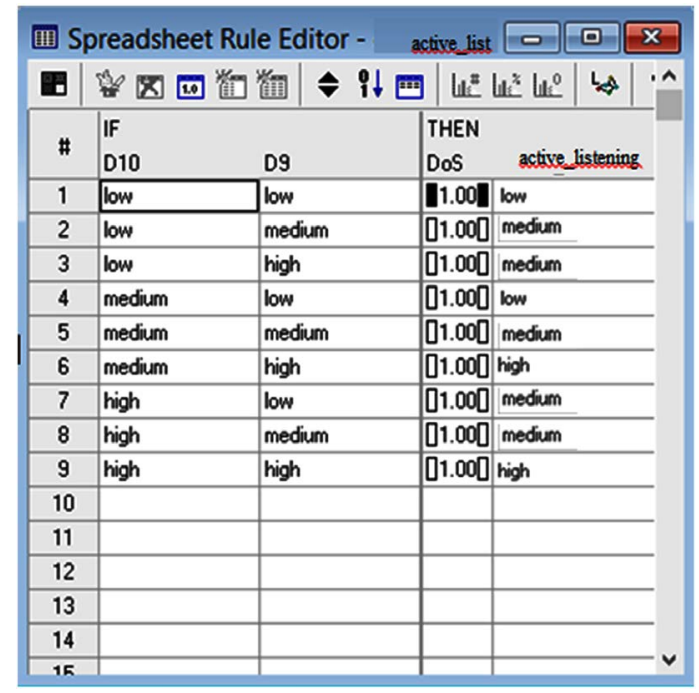

Figure 1. Example of rule block using the indicator “Active Listening". Own authorship (2019).

\section{Methodology}

\subsection{Development of a Bibliographic Portfolio}

To determine which soft skills are significant for the Engineering training, a Systematic Bibliographic Review (SBR) was conducted. To develop the SBR, the methodology developed by Pagani, Kovaleski and Resende (2015), called Methodi Ordinatio was chosen due to its consistency and results obtained, as can be seen in Campos et al. (2018), among others authors. The methodology steps are detailed below.

Step 1 and 2-Establishing the intention of research and preliminary search: the intention of this research is to understand the relation between two huge research areas: Humanities and Engineering. Therefore, for each of these two areas, two fronts of research were defined: Human Sciences and Human Skills for the first one, and Engineering Education and Graduate to the second one. The structure of these combinations is illustrated in Figure 2.

Steps 2 and 3-Definition of keywords and preliminary explanatory search: Keywords were defined for each research front. These keywords were grouped and crossed, forming 20 combinations as follows:

- Humanities and Engineering Education

- Humanities and Engineering Teaching

- Humanities and Degree in Engineering

- Humanities and Alumni* Engineering

- Humanities and Former Engineering Student ${ }^{\star}$

- Human ${ }^{\star}$ Science* and Engineering Education

- Human* Science* and Engineering Teaching

- Human ${ }^{\star}$ Science* $^{*}$ and Degree in Engineering

- Human ${ }^{\star}$ Science $^{\star}$ and Alumni* Engineering

- Human ${ }^{\star}$ Science ${ }^{\star}$ and Former Engineering Student* 


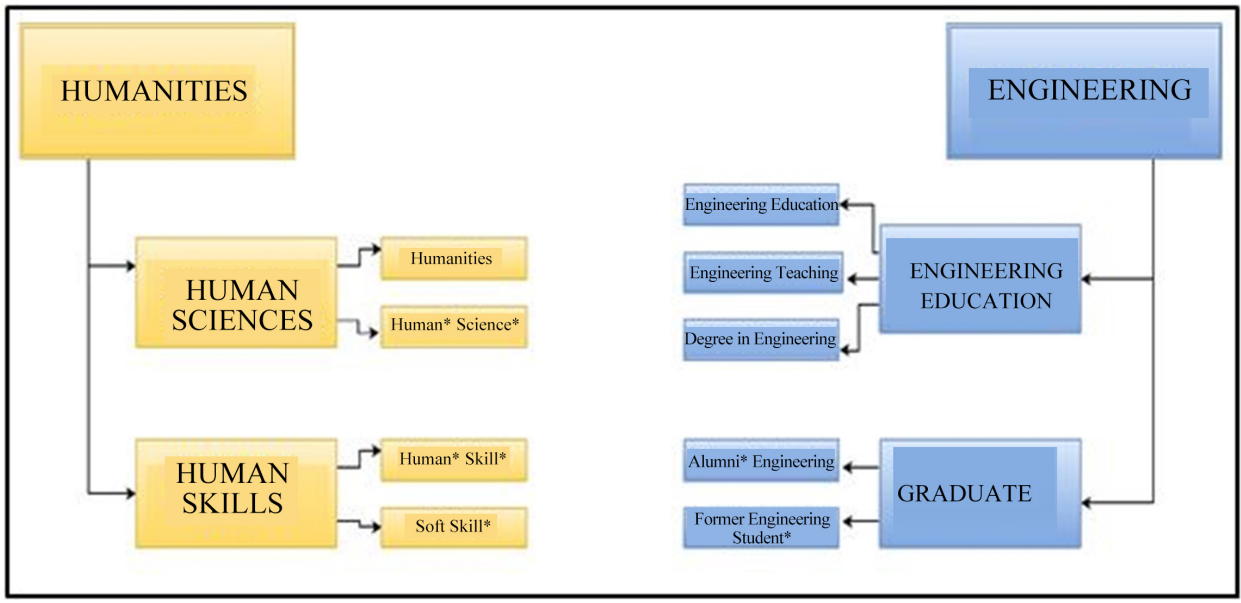

Figure 2. Keywords for SBR. Own authorship (2019).

- Human* Skill* and "Engineering Education"

- Human* Skill* and Engineering Teaching

- Human ${ }^{\star}$ Skill* and Degree in Engineering

- Human ${ }^{\star}$ Skill and Alumni* Engineering

- Human ${ }^{\star}$ Skill ${ }^{\star}$ and Former Engineering Student ${ }^{\star}$

- Soft Skill ${ }^{\star}$ and Engineering Education

- Soft Skill* and Engineering Teaching

- Soft Skill ${ }^{\star}$ and Degree in Engineering

- Soft Skill* and Alumni* Engineering

- Soft Skill ${ }^{\star}$ and Former Engineering Student*

For the articles search, from these 20 combinations, the databases which demonstrated greater proximity to the research area were chosen, namely: Science Direct, Web of Science and Scopus. Although the European Journal of Engineering Education (EJEE) is indexed in the Scopus scientific base, it was also used as a reference for searching individual articles, due to its self-indexed scope. Furthermore, an analysis was made of the articles published from 2006 to 2015, from the Journal of Engineering Education (JEE), because it is the magazine with the greatest impact factor (2.638) within the Engineering Education area, and is not indexed in these data base.

Steps 4 and 5-Final search on databases and selected journals: After the first search with the 20 combinations, 3951 articles were obtained. The journals which were exclusively related to the health area (or very specific areas) were discarded. With this, 2788 articles remained.

As some articles were indexed in more than one databases, it was necessary to remove duplicates, which lead to 2638 articles.

The next step was to read the 2638 titles and abstracts to see if they were in line with the proposed theme. Of these, 335 were in line with the expectations of the study scope, in Appendix 7. The number of articles collected, the filters used e the final number of articles that compose de database of the present work are shown in Table 1. 
From this point, categories were proposed to better analyze the articles. This categories were created based on the combination of two major areas of the Humanities field and two major areas of the Engineering field, as described in Table 2.

From this combination, 4 categories were obtained: Human Skills \& Graduate; Human Skills \& Engineering Education; Human Sciences \& Engineering Education; Human Sciences \& Graduates. Based on the scope of each of these 335 articles, they were classified into one of these 4 categories, as explained in Table 2.

Step 6-Identifying Impact factor, year and number of citations: The metrics of the article (Impact Factor) were obtained from Thomson's Reuters/Clarivate Analytics website. The number of citations was obtained from Google Scholar. These information-metrics and number of citations, along with the year of publication-is necessary to calculate the InOrdinatio, which is explained in details in the Step 7.

Step 7-Ranking and selection of articles: In order to have a scientific support of which articles are the most relevant for the reading and elaboration of the theoretical framework, an algorithm for the relevance ranking after SBR was used, the Methodi Ordinatio from Pagani, Kovaleski and Resende (2015), expressed in Equation (1):

$$
\text { InOrdinato }=\left(F_{i} / 1000\right) \alpha\left[10-\left(\text { Year }_{\text {search }}-\text { Year }_{\text {pub }}\right)\right]+\sum C_{i} .
$$

where:

$$
\begin{gathered}
F_{i}: \text { Impact Factor } \\
\text { Year }_{\text {search }}: \text { Year of search } \\
\text { Year }_{\text {pub }}: \text { Publication year } \\
C_{i}: \text { Number of citations in Google Scholar }
\end{gathered}
$$

A research in the Scielo database was also carried out, but no relevant articles were found.

As some articles were indexed in more than one scientific database, it was necessary to remove duplicates. The numbers of the articles captured, according to the keywords, are shown in Table 2.

The ranking and selection process was only necessary for the categories "Human Skills \& Engineering Education" and "Human Sciences \& Engineering

Table 1. Summary of the SBR with the keyword used to the present study.

\begin{tabular}{cc}
\hline $\begin{array}{c}\text { Number of articles without filter } \\
\text { Number of articles with disposal filter } \\
\text { (journals and key words out of the scope) }\end{array}$ & Number of articles \\
\hline $\begin{array}{c}\text { Number of articles after removal of duplicates } \\
\text { Number of articles after Titles and Abstract reading }\end{array}$ & 2788 \\
\hline
\end{tabular}

Source: Campos, 2019. 
Table 2. Distribution of the articles from the final portfolio into categories.

\begin{tabular}{cc}
\hline Category & Number of articles \\
\hline Human Skills \& Graduate & 00 \\
Human Skills \& Engineering Education & 85 \\
Human Sciences \& Engineering Education & 242 \\
Human Sciences \& Graduate & 08 \\
Total number of articles selected & 335 \\
\hline
\end{tabular}

Source: Campos, 2019.

Education". For the category of "Human Sciences \& Graduate", due to the low number of articles, all articles were read; for the "Human Skills \& Graduate" no articles were selected.

To define the threshold for which articles would compose the final portfolio for the "Human Skills \& Engineering Education" and "Human Sciences \& Engineering Education", the accumulated Index Ordinatio was used as a reference.

For this purpose, the articles of each of these categories were ordered in descending order according to their IO value (refer to Equation (1)). After ordering the articles, it was possible to calculate the accumulated IO (simple sum of the IO's of each article), as well as the relative percentage from each IO- $100 \%$ corresponded to the accumulated IO to each of the categories.

Table 3 and Table 4 show the ten first articles for the "Human Sciences \& Engineering Education" and "Human Skills \& Engineering Education", respectively. Columns 3 to 5 show the values used to calculate the IO. Column 6 shows the IO calculated for each article, Column 7 the accumulated IO and Column 8 the percentage of the accumulated IO.

It is important to notice that both tables are just a cutout of all the articles from each of the categories ( 242 for Table 3 and 85 for Table 4).

From the IO, accumulated IO and \% accumulated IO values, the graphics shown in Figure 3 and Figure 4 were constructed. The articles are shown in the horizontal axis, with the blue bar representing their IO. The orange curve illustrates the accumulated IO value. From this, it was established that the threshold for the articles that would compose the final portfolio would be $50 \%$ of the accumulated IO. This value is represented in both graphics by the pink horizontal line.

This percentage was a choice from the authors of the article, as per Pegani, Kovaleski e Resende (2015) statement that the threshold line is to be the author's choice and responsibility. With this threshold, a final portfolio from 59 articles was obtained.

\subsection{Bibliometric}

Bibliometric is a field of the area of the Library Science and the Information Science which applies statistical and mathematical models to analyze and con- 
struct indicators about the dynamics and evolution of the scientific information (Zupic \& Čater, 2015).

Table 3. Calculation of the Index Ordinatio for the keyword group of "Human Sciences" \& "Engineering Education".

\begin{tabular}{|c|c|c|c|c|c|c|c|c|}
\hline Article & Journal & $\begin{array}{l}\text { Impact } \\
\text { Factor }\end{array}$ & $\begin{array}{l}\text { \#Citations } \\
\text { in Google } \\
\text { Scholar }\end{array}$ & $\begin{array}{l}\text { Publication } \\
\text { year }\end{array}$ & $\begin{array}{l}\text { Numerical } \\
\text { Order in } \\
\text { the Master } \\
\text { Table }\end{array}$ & InOrdin & $\begin{array}{l}\mathrm{iO} \\
\text { Accumulated }\end{array}$ & $\begin{array}{l}\% \\
\text { Accumulated }\end{array}$ \\
\hline $\begin{array}{l}\text { El Impacto del Desarollo de } \\
\text { Habilidades para la } \\
\text { Competitividad: Evidencia } \\
\text { Empirica de una Comparación } \\
\text { entre Paises }\end{array}$ & $\begin{array}{l}\text { El Internacionalismo } \\
\text { Moderno }\end{array}$ & 0 & 183 & 2010 & 273 & 213 & 213 & 3.12 \\
\hline $\begin{array}{l}\text { The Humanities and Their Effect } \\
\text { on Engineering Education }\end{array}$ & $\begin{array}{l}\text { IEEE Communications } \\
\text { Magazine }\end{array}$ & 5.125 & 13 & 1990 & 747 & 148.1 & 361.1 & 5.30 \\
\hline $\begin{array}{l}\text { Introducing Professionalism } \\
\text { and Ethics in Engineering } \\
\text { Curriculum }\end{array}$ & $\begin{array}{l}\text { Journal of Engineering } \\
\text { Education }\end{array}$ & 0.538 & 15 & 1991 & 3205 & 140.5 & 501.7 & 7.37 \\
\hline $\begin{array}{l}\text { Integrating Communication and } \\
\text { Engineering Education: A Look } \\
\text { at Curricula, Courses and } \\
\text { Support Systems }\end{array}$ & $\begin{array}{l}\text { Journal of Professional } \\
\text { Issues in Engineering } \\
\text { Education }\end{array}$ & 0.559 & 73 & 2003 & 425 & 138.6 & 640.2 & 9.40 \\
\hline $\begin{array}{l}\text { When Science should be a } \\
\text { Humanity }\end{array}$ & New Scientist & 0.285 & 0 & 1991 & 2945 & 125.3 & 901.4 & 13.2 \\
\hline $\begin{array}{l}\text { Teaching "Soft" Skills to } \\
\text { Engineers }\end{array}$ & $\begin{array}{l}\text { International Journal of } \\
\text { Electrical Engineering } \\
\text { Education }\end{array}$ & 0.302 & 57 & 2003 & 312 & 122.3 & 1023 & 15.0 \\
\hline $\begin{array}{l}\text { Requirements upon Human } \\
\text { Competencies in Globally } \\
\text { Distributed Manufacturing }\end{array}$ & Computers in Industry & 1.685 & 29 & 1998 & 3506 & 120.7 & 1144.4 & 16.8 \\
\hline $\begin{array}{l}\text { Humanities for Undergraduate } \\
\text { Engineers: A Rich Paradox }\end{array}$ & $\begin{array}{l}\text { Journal of Engineering } \\
\text { Education }\end{array}$ & 0.559 & 05 & 1993 & 3471 & 120.6 & 1264.9 & 18.6 \\
\hline $\begin{array}{l}\text { The Good Engineer: Giving } \\
\text { Virtue its due in Engineering } \\
\text { Ethics }\end{array}$ & $\begin{array}{l}\text { Science and Engineering } \\
\text { Ethics }\end{array}$ & 1.454 & 78 & 2008 & 636 & 119.5 & 1384.4 & 20.3 \\
\hline $\begin{array}{l}\text { Non-Ethical Subjects in the } \\
\text { German Engineering } \\
\text { Curriculum: A Historical } \\
\text { Overview }\end{array}$ & Technology in Science & 0.185 & 0 & 1993 & 459 & 115.2 & 1499.6 & 22.0 \\
\hline $\begin{array}{l}\text { Strengthening Human Resources } \\
\text { for New and Renewable Energy } \\
\text { Technologies of the } 21^{\text {st }} \text { Century- } \\
\text { UNESCO Engineering } \\
\text { Education and Training } \\
\text { Programme }\end{array}$ & Renewable Energy & 3.404 & 13 & 1997 & 3701 & 111.4 & 1726.0 & 25.4 \\
\hline $\begin{array}{l}\text { Course on Engineering } \\
\text { Leadership }\end{array}$ & $\begin{array}{l}\text { Journal of Professional } \\
\text { Issues in Engineering } \\
\text { Education and Practice }\end{array}$ & 0.538 & 24 & 1999 & 251 & 109.5 & 1835.6 & 27.0 \\
\hline
\end{tabular}

Own authorship (2019). 
Table 4. Calculation of Index Ordinatio for the keywords group of "Human Skills" \& "Engineering Education".

\begin{tabular}{|c|c|c|c|c|c|c|c|c|}
\hline Article & Journal & $\begin{array}{l}\text { Impact } \\
\text { Factor }\end{array}$ & $\begin{array}{l}\text { \#Citations } \\
\text { in Google } \\
\text { Scholar }\end{array}$ & $\begin{array}{l}\text { Publication } \\
\text { year }\end{array}$ & $\begin{array}{l}\text { Numerical } \\
\text { Order in } \\
\text { the Master } \\
\text { Table }\end{array}$ & InOrdin & $\begin{array}{l}\text { iO } \\
\text { Accumulated }\end{array}$ & $\begin{array}{l}\% \\
\text { Accumulated }\end{array}$ \\
\hline $\begin{array}{l}\text { The Networking Company } \\
\text { Antecedents for Coping with } \\
\text { Relationships and Networks } \\
\text { Effectively }\end{array}$ & $\begin{array}{l}\text { Industrial Marketing } \\
\text { Management }\end{array}$ & 1.93 & 417 & 1999 & 2766 & 503.9 & 503.9 & 12.1 \\
\hline $\begin{array}{l}\text { Project Management Education: } \\
\text { The Human Skills Imperative }\end{array}$ & $\begin{array}{l}\text { International Journal } \\
\text { of Project Management }\end{array}$ & 2.885 & 201 & 2008 & 2060 & 243.9 & 747.8 & 18.0 \\
\hline A Skills Audit & $\begin{array}{l}\text { Training \& } \\
\text { Development Journal }\end{array}$ & 0 & 1 & 1980 & 1848 & 181 & 928.8 & 22.3 \\
\hline $\begin{array}{l}\text { Curriculum for an Engineering } \\
\text { Renaissance }\end{array}$ & $\begin{array}{l}\text { IEEE Transactions on } \\
\text { Education }\end{array}$ & 1.33 & 85 & 2003 & 1600 & 151.3 & 1080.1 & 26.0 \\
\hline $\begin{array}{l}\text { Flexible Firms, Skills and } \\
\text { Employment }\end{array}$ & $\begin{array}{l}\text { MPT Metallurgical Plant } \\
\text { and Technology } \\
\text { International }\end{array}$ & 0 & 45 & 1996 & 2239 & 145 & 1375.0 & 33.1 \\
\hline $\begin{array}{l}\text { Engineers Learn "Soft Skills The } \\
\text { Hard Way": Planting a Seed of } \\
\text { Leadership in Engineering } \\
\text { Classes }\end{array}$ & $\begin{array}{l}\text { Leadership Management } \\
\text { in Engineering }\end{array}$ & 0 & 92 & 2007 & 1408 & 137 & 1512.0 & 36.4 \\
\hline NASA's Educational Programs & $\begin{array}{l}\text { Government } \\
\text { Information Quarterly }\end{array}$ & 2.515 & 02 & 1990 & 1878 & 134.5 & 1646.5 & 39.6 \\
\hline $\begin{array}{l}\text { Engineering as a Liberal } \\
\text { Education for the } 21^{\text {st }} \text { Century }\end{array}$ & $\begin{array}{l}\text { Technical } \\
\text { Paper-Society of } \\
\text { Manufacturing } \\
\text { Engineers }\end{array}$ & 0 & 0 & 1996 & 2233 & 100 & 1746.5 & 42.0 \\
\hline $\begin{array}{l}\text { Coaches Safety Orientation and } \\
\text { Training Skills Program }\end{array}$ & $\begin{array}{l}\text { ASTM Special Technical } \\
\text { Publication }\end{array}$ & 0 & 01 & 1997 & 2257 & 96 & 1842.5 & 44.3 \\
\hline $\begin{array}{l}\text { Globalization, Curricula Reform } \\
\text { and the Consequences for } \\
\text { Engineers Working in an } \\
\text { International Company }\end{array}$ & $\begin{array}{l}\text { European Journal of } \\
\text { Engineering Education }\end{array}$ & 0.89 & 44 & 2006 & 1327 & 94.9 & 1937.4 & 47.0 \\
\hline $\begin{array}{l}\text { Social Competences and Personal } \\
\text { Ethical Development-Soft Skills } \\
\text { or a Need For Survival? }\end{array}$ & Technology and Society & 0 & 05 & 2000 & 2644 & 85 & 2114.8 & 50.9 \\
\hline $\begin{array}{l}\text { Enhancing Individual } \\
\text { Employability: The Perspective } \\
\text { of Engineering Graduates }\end{array}$ & Education + Training & 0 & 49 & 2010 & 1379 & 79 & 2193.8 & 52.8 \\
\hline $\begin{array}{l}\text { Engineers of Tomorrow and } \\
\text { Beyond Knowledge, Insight and } \\
\text { Skills that Need to Work Across } \\
\text { Borders }\end{array}$ & Age & 2.5 & 02 & 2002 & 1631 & 74.5 & 2268.3 & 54.5 \\
\hline
\end{tabular}

Own authorship (2019).

At this stage, bibliometric was performed on the 59 articles which compose the final portfolio of the research and bibliometric analysis. 


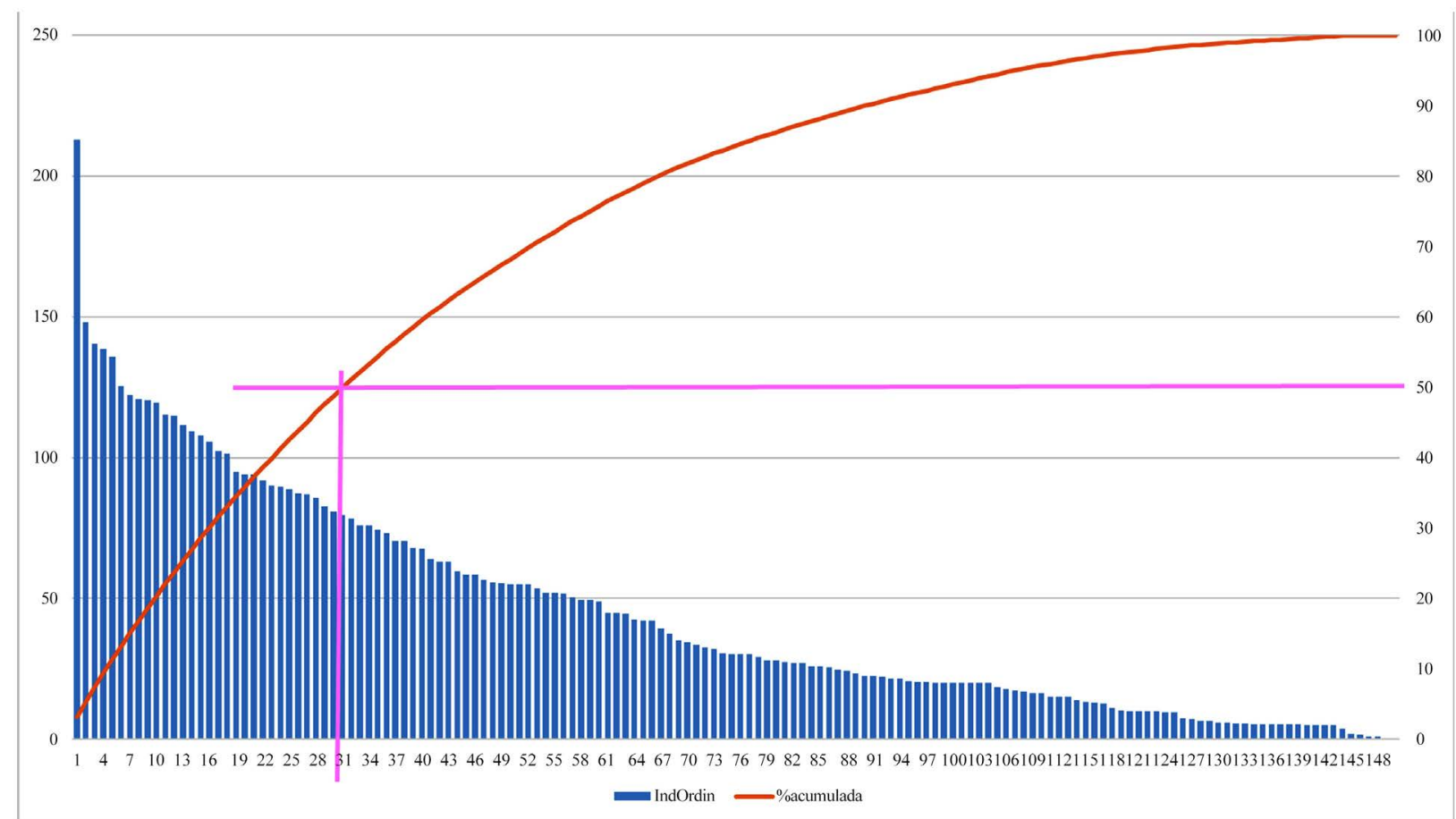

Figure 3. IO, accumulated IO and \% accumulated IO for the "Human Sciences \& Engineering Education" category. Own authorship (2019).

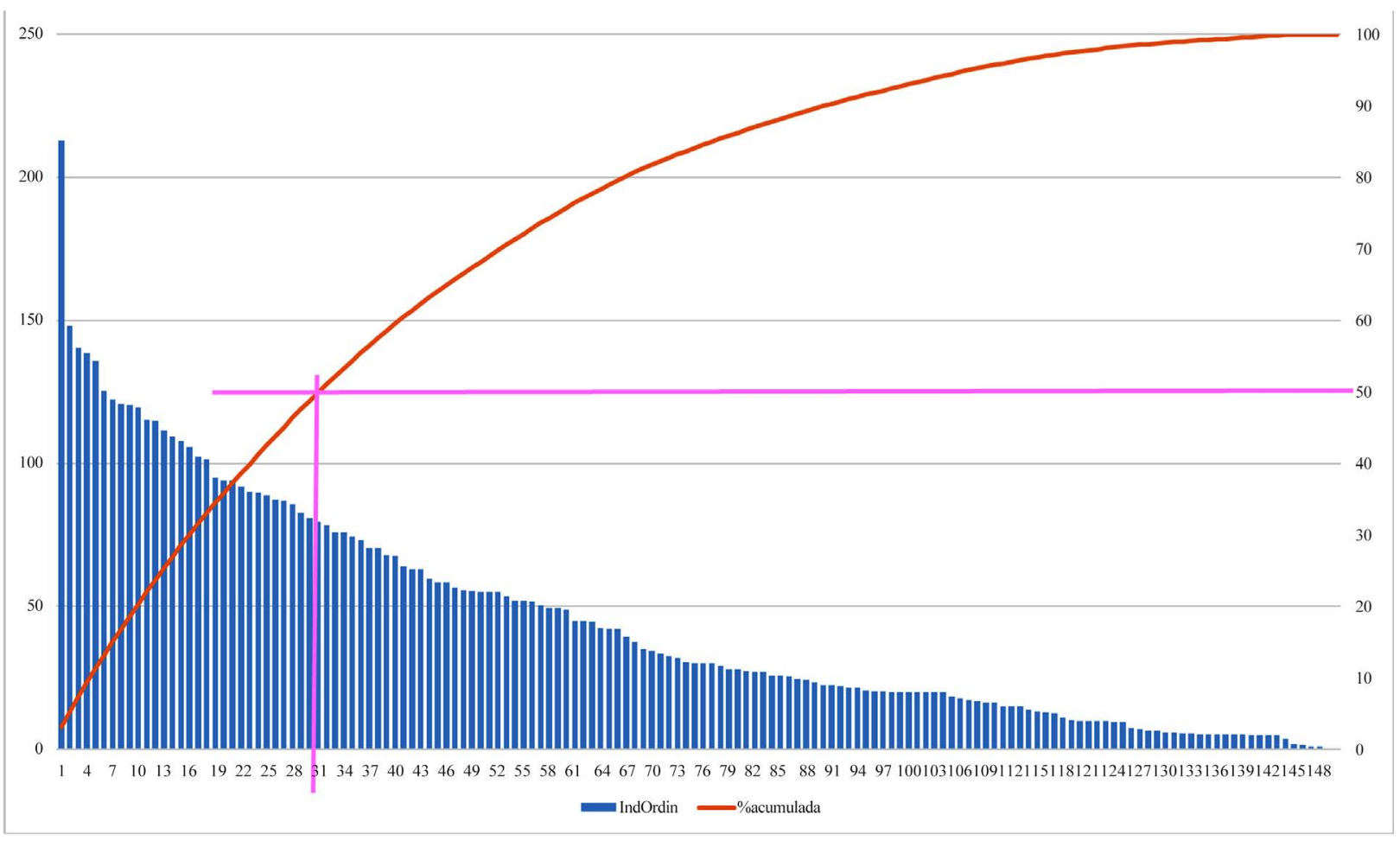

Figure 4. IO, accumulated IO and \% accumulated IO for the "Human Skills \& Engineering Education" category. Own authorship (2019).

The detailed study of the articles showed the soft skills, which were later classified into categories. Each time an article cited a given soft skill, this was com- 
puted into the research. Therefore, at the end of each article, the list of soft skills perceived as relevant in that work was obtained.

Moreover, for each article, it was also tracked how many times a given term, was cited either as a hard skill or a soft skill, as well as the number of times the term was said to be "necessary", "important" or as "neutral" or "unimportant".

Finally, it was also tracked the number of times that the definition of soft skills was given and the number of times the term appeared in the articles analyzed.

Table 5 shows the soft skills cited in the articles, as well as the values for each of the parameters mentioned in the previous paragraph.

Table 5. Calculation of Index Ordinatio for the keywords group of "Human Skills \& Graduate".

\begin{tabular}{|c|c|c|c|c|c|c|c|c|c|c|}
\hline & $\begin{array}{l}\text { Soft skills } \\
\text { obtained from } \\
\text { Systematic } \\
\text { Bibliographic } \\
\text { Review }\end{array}$ & $\begin{array}{l}\text { Number of } \\
\text { articles in } \\
\text { which the } \\
\text { soft skill } \\
\text { appears }\end{array}$ & $\begin{array}{l}\text { Number } \\
\text { of times } \\
\text { term } \\
\text { appears as } \\
\text { "hard skill" }\end{array}$ & $\begin{array}{l}\text { Number } \\
\text { of times } \\
\text { the term } \\
\text { appears as } \\
\text { "soft skill" }\end{array}$ & $\begin{array}{l}\text { Number } \\
\text { of times } \\
\text { term } \\
\text { suggests } \\
\text { "necessity" }\end{array}$ & $\begin{array}{l}\text { Number } \\
\text { of times the } \\
\text { term } \\
\text { suggests } \\
\text { "importance" }\end{array}$ & $\begin{array}{l}\text { Number } \\
\text { of time } \\
\text { the term } \\
\text { is "not } \\
\text { relevant" } \\
\text { or } \\
\text { "neutral" }\end{array}$ & $\begin{array}{l}\text { Number } \\
\text { of times } \\
\text { the term } \\
\text { appears as } \\
\text { a result of } \\
\text { a research }\end{array}$ & $\begin{array}{l}\text { Number } \\
\text { of times } \\
\text { the term } \\
\text { appears as } \\
\text { a } \\
\text { definition }\end{array}$ & $\begin{array}{l}\text { Total } \\
\text { number } \\
\text { of times } \\
\text { the term } \\
\text { appears in } \\
\text { the articles }\end{array}$ \\
\hline \multirow{5}{*}{ Communication } & $\begin{array}{l}\text { Oral } \\
\text { Communication }\end{array}$ & 47 & 0 & 165 & 147 & 18 & 24 & 0 & 0 & 354 \\
\hline & $\begin{array}{l}\text { Written } \\
\text { Communication }\end{array}$ & 45 & 0 & 130 & 108 & 21 & 25 & 1 & 0 & 285 \\
\hline & Active Listening & 16 & 0 & 44 & 34 & 10 & 7 & 0 & 0 & 95 \\
\hline & Reading & 19 & 0 & 19 & 15 & 4 & 30 & 0 & 0 & 68 \\
\hline & $\begin{array}{l}\text { Foreign } \\
\text { Language }\end{array}$ & 7 & 0 & 16 & 11 & 5 & 33 & 0 & 0 & 65 \\
\hline \multirow{3}{*}{$\begin{array}{l}\text { Critical } \\
\text { Thinking }\end{array}$} & Problem Solving & 27 & 45 & 99 & 0 & 0 & 5 & 0 & 0 & 149 \\
\hline & Open Mind & 23 & 0 & 16 & 11 & 5 & 33 & 0 & 1 & 66 \\
\hline & $\begin{array}{l}\text { Critical Thinking } \\
\text { per si }\end{array}$ & 10 & 0 & 23 & 22 & 0 & 6 & 1 & 2 & 54 \\
\hline \multirow{2}{*}{$\begin{array}{l}\text { Creative } \\
\text { Thinking }\end{array}$} & Creativity & 25 & 0 & 60 & 20 & 35 & 16 & 5 & 1 & 137 \\
\hline & Innovation & 20 & 5 & 219 & 209 & 15 & 16 & 3 & 0 & 467 \\
\hline \multirow{4}{*}{$\begin{array}{l}\text { Emotional } \\
\text { Intelligence }\end{array}$} & $\begin{array}{l}\text { Emotions } \\
\text { Control }\end{array}$ & 22 & 0 & 36 & 14 & 12 & 3 & 10 & 0 & 75 \\
\hline & $\begin{array}{l}\text { Lifelong } \\
\text { Learning }\end{array}$ & 18 & 0 & 55 & 21 & 34 & 3 & 0 & 0 & 113 \\
\hline & Motivation & 17 & 0 & 33 & 14 & 12 & 3 & 10 & 0 & 72 \\
\hline & Self-Direction & 1 & 0 & 1 & 1 & 0 & 0 & 0 & 0 & 2 \\
\hline \multirow{3}{*}{$\begin{array}{l}\text { Ethic } \\
\text { Perspective }\end{array}$} & Ethics & 36 & 0 & 607 & 475 & 131 & 424 & 1 & 0 & 1638 \\
\hline & Professionalism & 13 & 0 & 50 & 21 & 28 & 19 & 1 & 0 & 119 \\
\hline & $\begin{array}{l}\text { Social } \\
\text { Responsibility }\end{array}$ & 18 & 0 & 56 & 32 & 24 & 11 & 0 & 0 & 123 \\
\hline \multirow{3}{*}{$\begin{array}{l}\text { Team } \\
\text { Work }\end{array}$} & Multiculturalism & 55 & 0 & 215 & 125 & 59 & 25 & 18 & 0 & 442 \\
\hline & Leadership & 34 & 0 & 108 & 69 & 36 & 47 & 3 & 0 & 263 \\
\hline & Networking & 19 & 0 & 33 & 16 & 17 & 13 & 0 & 0 & 79 \\
\hline
\end{tabular}

Own authorship (2019). 
Based on bibliometrics, a top-down tree-shaped model (shown in Figure 11) was elaborated with fuzzy logic to evaluate the soft skills that most appeared in the Systematic Bibliographic Review (Campos et al., 2020a), combined with those ordered by the OECD employability reports (OECD, 2015; OECD, 2016a, 2016b) and the report P21 (Casner-Lotto \& Barrington, 2006), as already explained in the Section 2-Theoretical Reference.

The fuzzy logic operates through the intersection of fuzzy sets, considering degrees of pertinence for each set. The classical proposition differs from the fuzzy fundamentally by its truth zone values. In traditional set theory of classical logic, an element may or may not belong to a set. However, in the theory of fuzzy sets, an element of a given U Universe can be defined mathematically by a value representing its degree or level of belonging to the set. This membership value is in a range that goes from: "this element does not belong to the set" (0) to "this element belongs 100\% to the set" (1) (Bonventi \& Costa, 2000; Boutros \& Chen, 2011; Takáč, 2014).

An example of how fuzzy logic was used for this specific work, is in the fuzzification of the soft skill "critical thinking", which assumes truth-values by means of fuzzy sets with the other thematic soft skills "communication", "team work", "ethical perspective", "emotional control" and "creative thinking", according to the degrees of pertinence. According to Campos Filho (2004) and Chakraverty \& Behera (2013), a fuzzy set is completely characterized by its membership vector, with individual multivalent degrees of membership within the 0.1 numerical range. These degrees of pertinence can be considered as a measurement to express the possibility of a given element being a member of a fuzzy set. Thus, a fuzzy pertinence vector is also called a possibility vector or a possibility distribution vector.

As the name already suggests, this logic is fuzzy, and it is interesting to notice that, differently from the Boolean logic, when the sets are represented using the Veen Diagram, they do not need to cross to have an intersection region. Figure 5 shows a demonstration of this phenomenon, in which the clouds of the fuzzy sets intersect, forming a fuzzy intersection.

In Figure 5, the elements of the cloud of set A intersect with the elements of the cloud of set $\mathrm{B}$, forming an intersection of sets of the fuzzy type, which is not exact, but rather diffuse, similar to human reasoning.

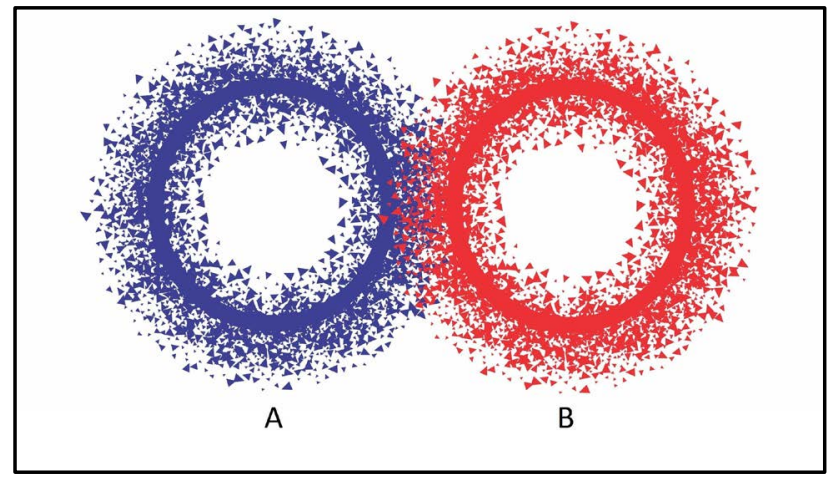

Figure 5. Fuzzy sets with intersecting clouds. Own authorship (2019). 
In this sense, fuzzy logic is a way to manage uncertainties (Caiado et al., 2021; Takáč, 2014) and its use is very appropriate to treat data collected from the $\mathrm{Hu}-$ man Sciences and measure the levels of uncertainty inherent to human communication.

The advantage of Boolean logic, with its crisp values, is accuracy. The disadvantage is In Figure 6, the letters " $D$ " represent the input data, that is, the questions asked to the participants to feed the hierarchy constructed with the FuzzyTECH software The fuzzy logic calculates the existing pertinence between D3 and D4, for example, to form the soft skill "open mind" encountered in the SBR. Afterwards, the fuzzy operation calculated how much "open mind" and "problem solving" impact the fuzzy sets, to form the thematic group which is also a soft skill: "critical thinking".

This process is repeated for all the thematic groups, forming the other soft skills of this modelling. Later, "critical thinking" will be fuzzyfied with the other 5 macro soft skills (those which compose the thematic group) to generate a result, which is the level of that soft skill within the investigated Engineering course. This illustrated in the hierarchical scheme called top-down tree.

The construction of the Top-down Tree was based on the intended result, and has 4 hierarchical levels (Figure 7). The fourth level, which represents the Result (diagnosis in soft skills development in Engineering training), comes from the aggregation of the indexes. The indices obtained from the aggregation of soft skills from thematic groups (indicators) make up the third level. The indicators constitute the second level and are the soft skills obtained from the bibliometric of SBR, broken down into guidelines inspired by the P21 report (Casner-Lotto \& Barrington, 2006), which represent the first level, as well as the tree's input data .

This hierarchy represents a simplified cut of the Model mounted on the fuzzyTECH tree, showing the logical sequence to achieve the result, which is the diagnosis of soft skills development in Engineering training.

\section{Calibration of the FuzzyTECH Software}

In order to feed the data into the software used in this research, the blocks were weighed by the "Degree of Support" or DoS, which is a calibration function of the fuzzyTECH Software itself.

This calibration occurs through the assignment of weights, according to the data obtained by the interviewees' opinions, being 40 organizational Psychologists, chosen at random. For Gondim, Borges-Andrade and Bastos (2017), this area of Psychology is responsible for promoting strategies for improving the work environment. These people have a greater proximity to the environment of the organizations, being then elected to assess the inferences of the soft skills among themselves.

For this purpose, the Psychologists answered the questionnaire included in Appendix 1. For the weighting of the data, the Likert scale was used, associated with the Delphi method with scores from 0 to 10 , in which values were provided related to their respective perceptions about the inferences that soft skills present. 
For Vieira and Dalmoro (2008), when the answers and results are dispersed, the Likert scale may not be the most appropriate methodological tool, which suggests the need to have a complementary measurement strategy. In order to have greater reliability in the answers, the Delphi methodology was used, which, for Fagundes (2015), associated with the Likert scale, allows the results converging, reducing the dispersion of the obtained values.
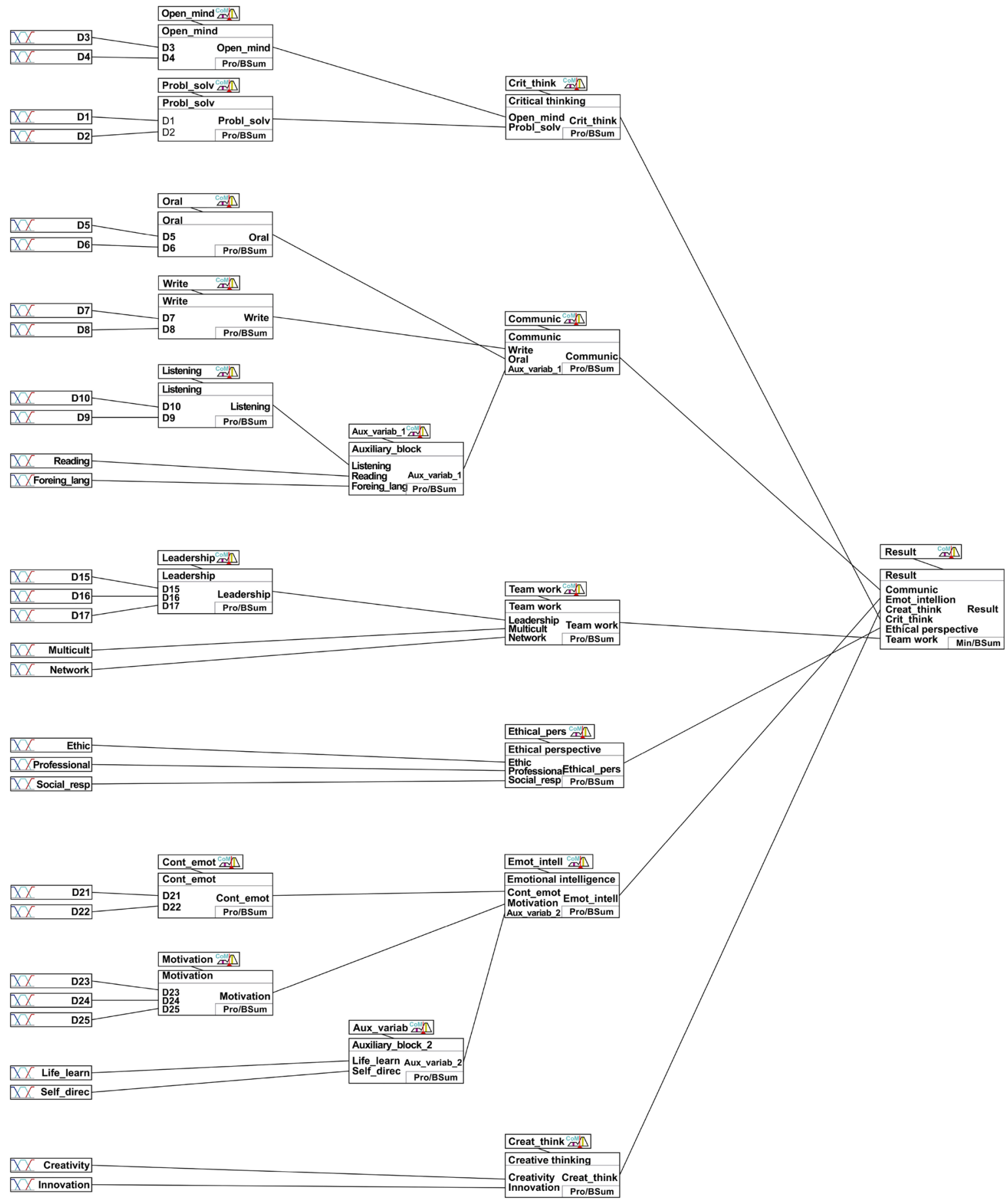

Figure 6. Top-Down tree model. Source: Campos (2019). 


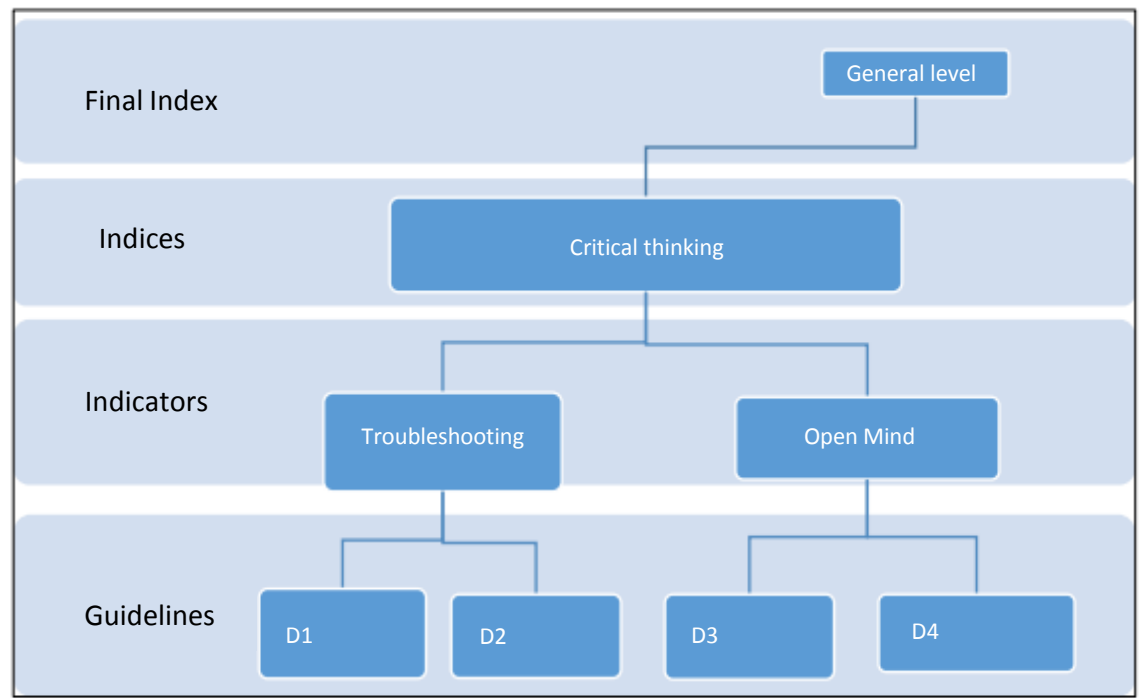

Figure 7. Simplified scheme of the proposed model. Source: Own autorship. Legend: D1Find Solutions using multidisciplinary knowledge; D2-Use knowledge, data and facts to solve problems at work; D3-Ability to solve problems in a pacific manner; D4-Openness to suggestions, new ideas and contrary opinions.

For Fagundes (2015), the Likert scale is carried out using the weighted average, as shown in Table 6, which exemplifies the model that will be used for data valuation and insertion in the FuzzyTECH software.

Equation (3) demonstrates the calculation based on the results of Table 6.

$$
\begin{gathered}
\text { Weighted average }=(2 \times 5)+(4 \times 6)+(3 \times 7)+(1 \times 8)=63 \\
A R=63 /(2+4+1+3)=6.3
\end{gathered}
$$

The Delphi method aims to bring responses closer to a collective consensus, reaching a more representative value than that of the isolated opinions. Leading opinions may have an influence on the results of the entire group (Giovinazzo, 2001).

For the proper use of the aforementioned method, members of a group of experts familiar with the study themes were consulted-for the present study, the organizational psychologists were the targeted group. After the elaboration of the questionnaires, they were sent to the respondents individually, and returned to the researchers after completion. After analysis, the questionnaires were sent back to the respondents, in order to reduce the dispersion of the results (Candido et al., 2007; Wright et al., 2000). For the scientific legitimacy of this method, three points were respected: the anonymity of the participants, the statistical evaluation of the distribution of the data obtained and the return of the responses of the group members, so that the new assessment can be made (Listone \& Turoff, 2002; Wright et al., 2000; Martino, 1993).

In the last round, the same questionnaire was used, for the same Psychology professionals, who then had the Weighted Average of the result of the previous stage, referring to all respondents, as well as the values assigned by themselves. 
Table 6. Calculation of Index Ordinatio for the keywords group of "Human Skills \& Graduate".

\begin{tabular}{cccccccccccc}
\hline \multicolumn{1}{c}{ Question } & \multicolumn{1}{c}{ Attributed weighs and responses frequency } & AR \\
\hline $\begin{array}{c}\text { How much "Ability to present ideas } \\
\text { clearly during a conversation" impacts } \\
\text { "Oral Communication" }\end{array}$ & 0 & 1 & 2 & 3 & 4 & 5 & 6 & 7 & 8 & 9 & 10 \\
\end{tabular}

Source: Adapted from: Fagundes (2015).

Based on this, they decided whether they would maintain or modify their responses from the first round. This step increases the reliability of the results, as the change of some perceptions reduces the values dispersion (Fagundes, 2015).

Finally, the modeling developed by one of the authors of this study (Campos, 2019), was calibrated in all its guidelines, indexes and indicators, thus providing the final result (indicator): diagnosis of the soft skills development for Engineering training, as elucidated in Table 7. This calibration is presented as complementation of the developed model and it serves to the purpose of specialists being able to determine how much a soft skill impacts another one, attending the complete development of the fuzzy logic within the present work.

The values obtained with the weighting of the Psychologists were entered in the FuzzyTECH Software to calibrate the model. Copies of the questionnaires suggested to be applied with the targeted audience composed of students, graduates, professors and employers of Engineers were also attached to this study in the Appendices 1-6. This covers the entire development of the instrument for diagnosing the soft skills development in Engineering training.

\section{Application Simulation}

Considering a hypothetical application, utilizing the possibility of simulation that the model developed by the authors provide, using fictitious groups of teachers, graduates, students and employers of engineers to answer the questionnaires contained in Appendices 1-6, the results obtained are as follows, shown in Table 8.

Table 8 shows that teachers are out of line with the expectations of the labor market according to the managers' opinion. This discrepancy in results shows that there is room for improvement in order to reach indexes that meet the job market's regarding Engineers' soft skills. Taking into consideration the areas of each group of professors, it is clear that the "Material" is the worst rated one, with low values for "public speaking", and "multiculturalism", which make up the macro soft skills macro of communication and teamwork, respectively.

The scientific results show that "Communication" and "Team Work" were the skills with the lowest indexes for professors. Based on these evidences, coordinators of Engineering courses can turn their efforts to include in their course curricula the development of these skills. Investment could also be made in professor training, teaching methodology, adaptation of bibliography as well as adjustment of workload and increase or decrease in the subjects availability. Each institution has to evaluate which possibilities are feasible for them to leverage 


\section{these rates.}

Each of the soft skills can be analyzed either in their macro groups or isolated to identify the weaknesses and potential for improvement of Engineering courses that aims to investigate the levels of soft skills in their students' training.

Table 7. Average of the values assigned by psychologists, after application of the Delphi method.

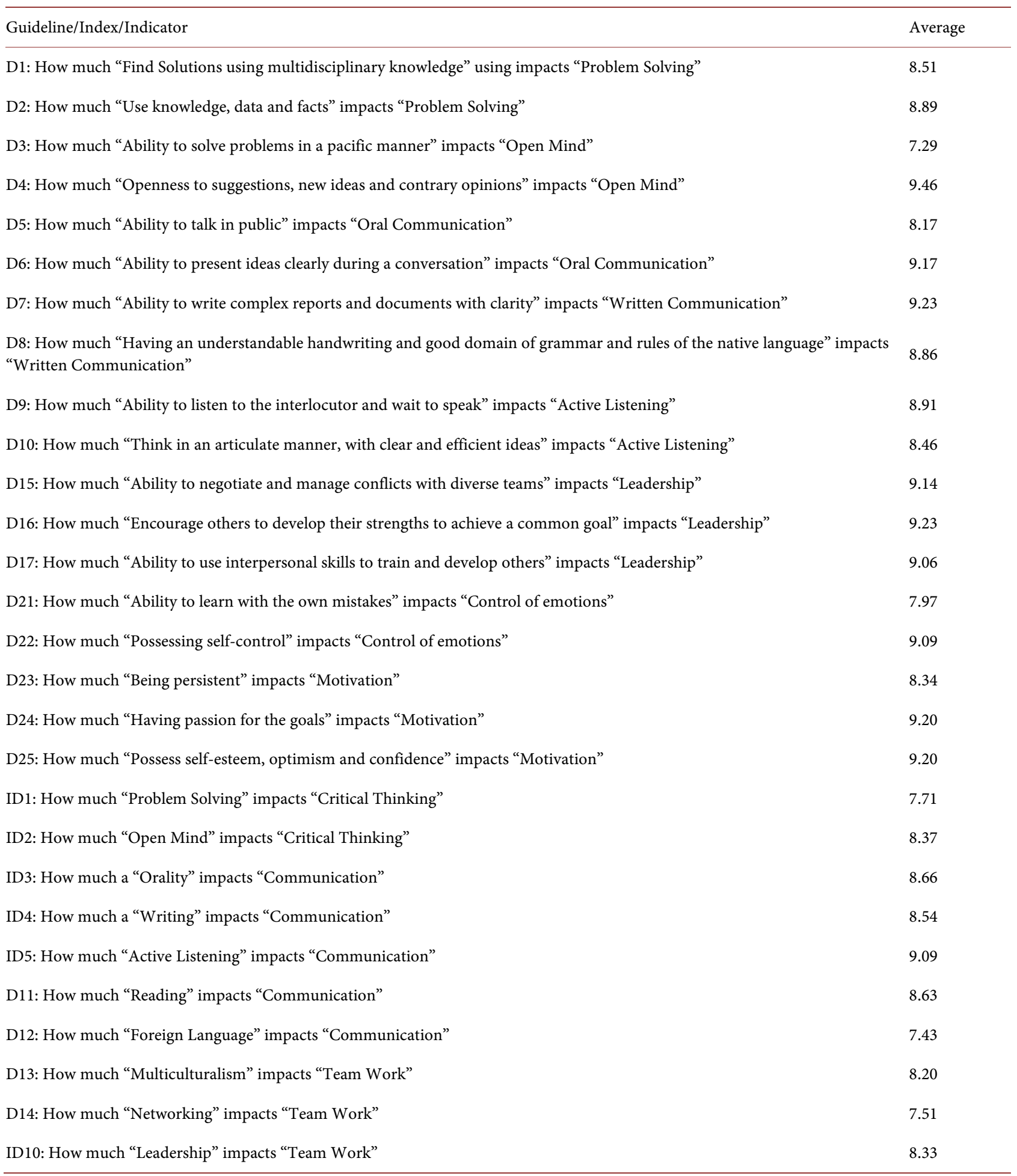




\section{Continued}

ID18: How much "Personal Ethics" impacts "Ethic Perspective"

D19: How much que "Professionalism" impacts "Ethic Perspective"

D20: How much que "Social Responsibility" impacts "Ethic Perspective"

ID14: How much "Control of Emotions" impacts "Emotional Intelligence"

ID15: How much "Motivation" impacts "Emotional Intelligence"

D26: How much "Lifelong Learning" impacts "Emotional Intelligence"

D27: How much "Self-Direction" impacts "Emotional Intelligence"

D28: How much "Creativity" impacts "Creative Thinking"

D29: How much "Innovation" impacts "Creative Thinking"

IC1: How much "Critical Thinking" impacts the soft skills of an Engineer

IC2: How much "Communication" Impacts the soft skills of an Engineer

IC3: How much "Team Work" impacts the soft skills of an Engineer

IC4: How much "Ethical Perspective" impacts the soft skills of an Engineer

IC5: How much "Emotional Intelligence" impacts the soft skills of an Engineer

IC6: How much "Creative Thinking" impacts the soft skills of an Engineer.

7.98

Source: Campos (2019).

Table 8. All fuzzy averages for all socioemotional guidelines and skills.

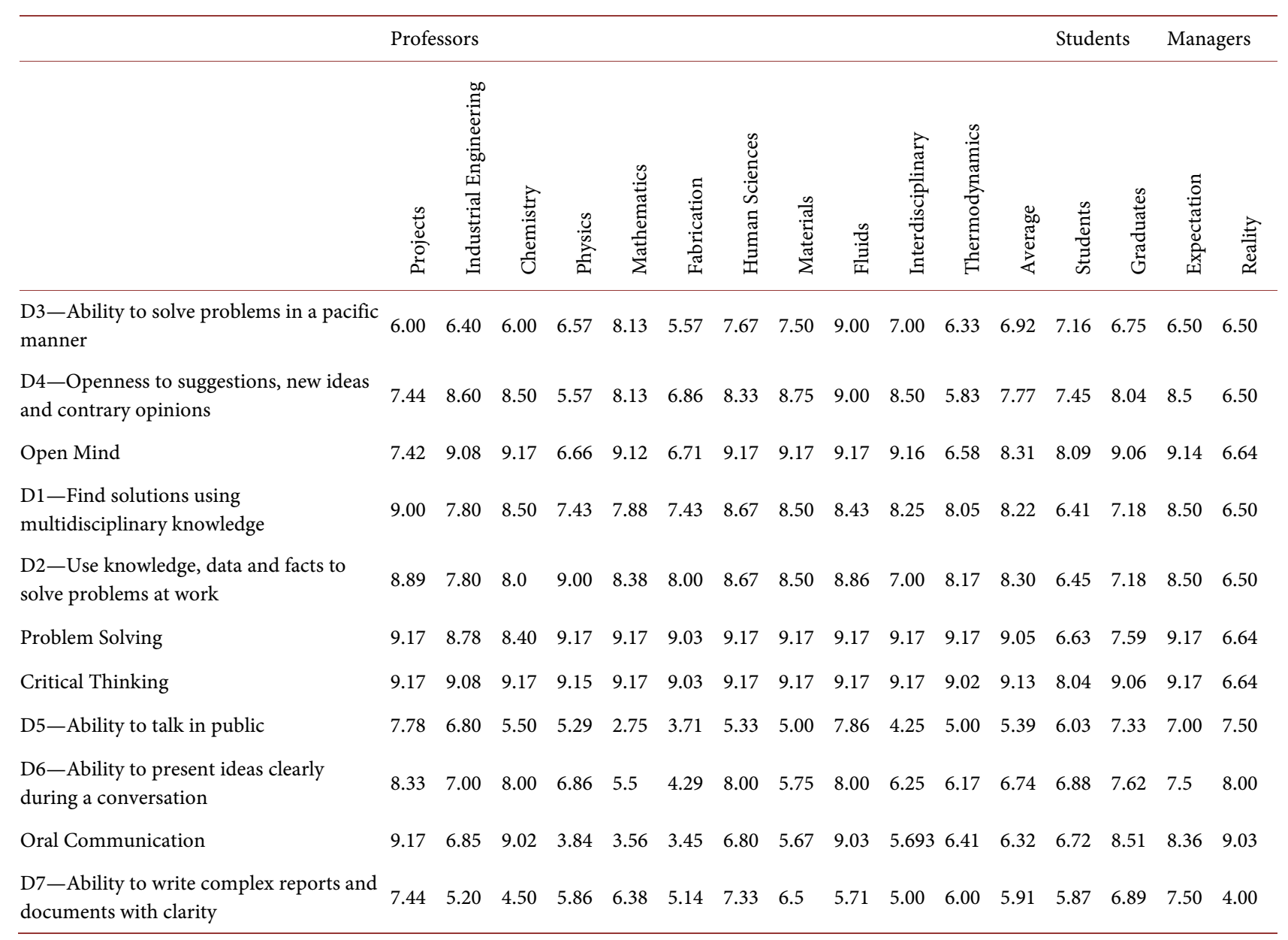




\section{Continued}

D8-Having an understandable

handwriting and good domain of

$\begin{array}{llllllllllllllll}6.44 & 5.60 & 4.00 & 6.00 & 5.25 & 4.71 & 4.67 & 6.00 & 5.86 & 4.75 & 4.17 & 5.22 & 6.24 & 6.60 & 7.50 & 5.50\end{array}$

grammar and rules of the native language

Written Communication

$\begin{array}{llllllllllllllll}6.67 & 5.45 & 3.73 & 6.27 & 6.60 & 4.94 & 6.65 & 6.35 & 6.14 & 4.95 & 5.20 & 5.72 & 6.51 & 6.73 & 8.33 & 4.32\end{array}$

D10-Think in an articulate manner, with clear and efficient ideas

$\begin{array}{llllllllllllllll}8.89 & 7.20 & 8.50 & 8.29 & 8.88 & 5.29 & 9.00 & 8.00 & 8.00 & 7.75 & 8.50 & 8.03 & 7.12 & 7.69 & 7.00 & 5.00\end{array}$

D9-Ability to listen the interlocutor and wait to speak

$\begin{array}{llllllllllllllll}6.78 & 6.60 & 7.50 & 6.43 & 7.38 & 4.29 & 6.33 & 7.50 & 8.14 & 6.25 & 7.83 & 6.82 & 7.34 & 7.22 & 5.50 & 5.00\end{array}$

Active Listening

Reading

$\begin{array}{llllllllllllllll}9.11 & 7.12 & 9.17 & 9.09 & 9.17 & 4.52 & 9.02 & 9.03 & 9.13 & 8.28 & 9.17 & 8.44 & 7.79 & 8.62 & 7.02 & 5.000\end{array}$

Foreign Language

Auxiliary Variable

$\begin{array}{llllllllllllllll}8.89 & 7.00 & 7.5 & 8.86 & 9.13 & 6.86 & 8.33 & 8.25 & 8.43 & 7.75 & 7.33 & 8.03 & 7.36 & 8.09 & 8.50 & 6.5\end{array}$

$\begin{array}{llllllllllllllll}4.78 & 1.60 & 3.00 & 2.29 & 1.38 & 4.71 & 3.00 & 5.75 & 5.14 & 4.5 & 6.67 & 3.89 & 5.1 & 4.29 & 5.50 & 5.50\end{array}$

$\begin{array}{llllllllllllllll}6.67 & 5.44 & 6.57 & 6.62 & 6.67 & 5.18 & 6.57 & 7.69 & 6.68 & 6.44 & 7.35 & 6.53 & 6.68 & 6.63 & 7.00 & 5.25\end{array}$

Communication

D15-Ability to negotiate and manage conflicts with diverse teams

$\begin{array}{llllllllllllllll}6.67 & 5.95 & 6.35 & 5.41 & 5.22 & 4.95 & 6.65 & 6.65 & 6.69 & 5.58 & 5.94 & 6.00 & 6.69 & 6.72 & 7.92 & 5.89\end{array}$

$\begin{array}{llllllllllllllll}8.78 & 6.20 & 3.50 & 6.43 & 5.88 & 5.29 & 6.67 & 7.50 & 6.71 & 5.25 & 4.67 & 6.08 & 6.87 & 7.15 & 6.50 & 6.00\end{array}$

D16-Encourage others to develop their strengths to achieve a common goal

$\begin{array}{llllllllllllllll}8.78 & 6.20 & 3.00 & 6.57 & 7.38 & 5.43 & 6.67 & 6.75 & 7.29 & 5.25 & 6.00 & 6.30 & 6.37 & 6.67 & 6.00 & 5.00\end{array}$

D17-Ability to use interpersonal skills to train and develop others

$\begin{array}{llllllllllllllll}9.22 & 7.00 & 4.50 & 7.14 & 7.00 & 4.57 & 6.67 & 6.75 & 8.29 & 5.25 & 6.17 & 6.60 & 6.20 & 6.58 & 6.00 & 5.00\end{array}$

Leadership

Multiculturalism

$\begin{array}{llllllllllllllll}9.17 & 6.64 & 3.35 & 6.67 & 6.72 & 5.01 & 6.67 & 6.67 & 7.33 & 5.00 & 5.92 & 6.29 & 6.657 & 6.67 & 6.50 & 5.00\end{array}$

Networking

Team work

$\begin{array}{llllllllllllllll}5.00 & 4.80 & 8.50 & 5.43 & 6.25 & 4.43 & 6.67 & 5.50 & 8.14 & 4.00 & 4.00 & 5.70 & 7.51 & 7.76 & 7 & 4.50\end{array}$

$\begin{array}{llllllllllllllll}9.22 & 6.00 & 7.00 & 7.43 & 8.13 & 6.43 & 6.67 & 7.25 & 8.86 & 5.00 & 5.33 & 7.03 & 7.47 & 7.93 & 5.5 & 8.00\end{array}$

$\begin{array}{llllllllllllllll}6.67 & 6.11 & 6.67 & 6.67 & 6.71 & 5.005 & 6.67 & 6.67 & 9.135 & 5 & 5.01 & 6.39 & 8.44 & 8.44 & 6.54 & 6.32\end{array}$

Ethics

Professionalism

$\begin{array}{llllllllllllllll}9.33 & 7.00 & 6.00 & 8.86 & 8.38 & 6.71 & 9.00 & 6.00 & 9.00 & 7.50 & 7.83 & 7.78 & 7.89 & 8.07 & 9 & 8.50\end{array}$

Social Responsibility

Ethical Perspective

D21-Ability to Learn with the own mistakes.

D22-Possessing self-control

Control of Emotions

D23-Being persistent

D24-Having passion for the goals

D25-Possessing self-esteem, optimism and confidence

Motivation

Lifelong Learning

Self-Direction

$\begin{array}{llllllllllllllll}9.56 & 7.00 & 9.00 & 8.57 & 8.88 & 7.56 & 9.00 & 7.75 & 9.29 & 8.50 & 7.50 & 8.42 & 8.19 & 8.24 & 8 & 8.00\end{array}$

$\begin{array}{llllllllllllllll}9.78 & 6.60 & 8.50 & 7.86 & 7.88 & 5.57 & 8.33 & 7.00 & 8.71 & 4.25 & 6.83 & 7.39 & 7.44 & 7.85 & 6.5 & 5.50\end{array}$

$\begin{array}{llllllllllllllll}9.17 & 6.80 & 9.17 & 9.17 & 9.17 & 6.67 & 9.170 & 6.929 & 9.17 & 6.67 & 7.65 & 8.16 & 8.86 & 9.06 & 8.96 & 7.013\end{array}$

$\begin{array}{llllllllllllllll}9.11 & 6.60 & 8.00 & 8.14 & 8.63 & 7.29 & 9.33 & 7.50 & 8.57 & 7.50 & 8.17 & 8.08 & 7.97 & 7.87 & 6.5 & 7.00\end{array}$

$\begin{array}{llllllllllllllll}8.9 & 5.2 & 9.0 & 6.7 & 7.3 & 5.7 & 6.7 & 6.0 & 8.6 & 6.5 & 8.2 & 7.15 & 6.9 & 7.5 & 6.5 & 6.0\end{array}$

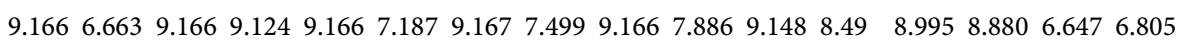

$\begin{array}{llllllllllllllll}9.33 & 3.80 & 9.50 & 8.43 & 8.25 & 7.29 & 8.67 & 6.50 & 9.43 & 6.50 & 8.67 & 7.85 & 7.23 & 8.38 & 7 & 7.50\end{array}$

$\begin{array}{llllllllllllllll}9.33 & 3.00 & 7.00 & 7.57 & 8.38 & 6.43 & 9.00 & 6.75 & 9.29 & 5.50 & 8.33 & 7.33 & 6.78 & 7.65 & 8 & 7.50\end{array}$

$\begin{array}{llllllllllllllll}9.22 & 3.40 & 8.50 & 7.14 & 7.88 & 7.71 & 8.33 & 6.75 & 9.29 & 5.50 & 7.33 & 7.37 & 5.57 & 7.11 & 6.5 & 7.50\end{array}$

$\begin{array}{llllllllllllllll}9.17 & 3.34 & 9.17 & 8.34 & 9.16 & 7.18 & 9.16 & 6.68 & 9.16 & 5.58 & 9.16 & 7.83 & 6.67 & 8.50 & 6.80 & 7.91\end{array}$

$\begin{array}{llllllllllllllll}9.80 & 7.0 & 8.0 & 8.0 & 8.60 & 7.90 & 9.00 & 7.50 & 9.00 & 9.80 & 8.7 & 8.47 & 7.8 & 8.5 & 8.5 & 7.5\end{array}$

$\begin{array}{llllllllllllllll}9.60 & 6.4 & 8.0 & 8.1 & 8.6 & 7.10 & 8.30 & 5.30 & 8.0 & 8.80 & 8.5 & 7.88 & 7.2 & 7.8 & 7.5 & 6.50\end{array}$

Auxiliary Variable 2

Emotional Intelligence

$\begin{array}{llllllllllllllll}9.17 & 6.81 & 9.03 & 9.10 & 9.17 & 8.92 & 9.17 & 6.78 & 9.17 & 9.17 & 9.17 & 8.69 & 8.76 & 9.17 & 9.166 & 7.88\end{array}$

$\begin{array}{llllllllllllllll}9.16 & 5.100 & 9.16 & 8.98 & 9.16 & 7.85 & 9.16 & 6.81 & 9.16 & 7.47 & 9.16 & 8.29 & 8.52 & 8.88 & 6.83 & 7.67\end{array}$

Creativity

$\begin{array}{llllllllllllllll}9.33 & 7.00 & 7.50 & 7.00 & 8.63 & 7.14 & 9.00 & 6.50 & 9.14 & 9.50 & 8.00 & 8.07 & 6.94 & 6.91 & 7.50 & 6.50\end{array}$

Innovation

$\begin{array}{llllllllllllllll}9.44 & 5.80 & 8.50 & 8.43 & 8.00 & 6.86 & 9.00 & 5.25 & 9.43 & 8.00 & 7.67 & 7.85 & 6.42 & 6.51 & 7.50 & 6.50\end{array}$

Creative Thinking

$\begin{array}{llllllllllllllll}9.16 & 6.80 & 9.16 & 9.16 & 9.16 & 7.07 & 9.16 & 6.64 & 9.16 & 9.16 & 9.02 & 8.52 & 6.75 & 6.73 & 8.33 & 6.64\end{array}$

RESULTS

$\begin{array}{llllllllllllllll}9.16 & 6.67 & 9.16 & 9.16 & 9.16 & 6.87 & 9.18 & 6.66 & 9.16 & 7.83 & 9.16 & 8.38 & 9.16 & 9.16 & 9.16 & 6.77\end{array}$ 


\section{Results and Conclusion}

The proposed model was simulated in the present study, but also validated through its application in a case study involving students, teachers and graduates of the Federal Technological University of Paraná, in Brazil, as well as Engineers' employers. The targeted audience chosen for the validation was broad and representative with respect to the universe of the Engineering training. It involved 375 participants, who answered the questionnaires proposed in Appendices 1-6. The results of the application are detailed in the doctorate thesis from Campos (2019) and the model proved to provide consistent and coherent results.

The presented model is robust, as it allows the same guidelines to be applied in any Engineering courses, as long as it adapts to the expected time and space; in addition to covering a bibliographic review of the last 15 years of publications on the subject, in 4 databases and two journals with a high impact factor-which were essential to give the modeling reliability, equivalence, consistency, stability and shelf life.

The reliability of the data collection tool makes it possible to repeat a result in a solid manner (Williamson \& Piattoeva, 2019). The equivalence of a research tool, on the other hand, relates to the level of agreement between at least two observers, with respect to the scores (Ahn et al., 2019). Both characteristics were explored in this work using the Delphi method, aiming to take the answers of the 40 organizational Psychologists, as well as for the calibration of the FuzzyTECH Software, in order to provide a collective consensus of ideas, demonstrating the most representative values, rather than isolated opinions.

The equivalence of a research tool refers to the agreement between at least 2 observers with respect to the data obtained with the tool (Ahn et al., 2019). Both points cited were addressed in this research using the Delphi method, starting from the integration of the responses of 40 Psychologists to the calibration of the FuzzyTECH Software, aiming the collective consensus of the data and preserving the subjective content of the collected data.

Regarding the stability of the tool, it concerns the similarity of the data obtained at different times, which can be evaluated by test-retest, applying the same measure in other times (Souza, Alexandre, \& Guirardello, 2017). The test-retest was carried out in the modeling with several simulations in the FuzzyTECH Software for the analysis and interpretation of the data, which proved to be convergent and stable.

With respect to the validity of the research tool, Fadzil and Saat (2019) state that it is the capacity that the tool has to measure what it is proposed to measure. This characteristic is present in this model, by answering the research question "How to develop a fuzzy modeling to diagnose soft skills in Engineering training". It has shown to be coherent and consolidated in concise manner.

For Umanailo et al. (2019), the consistency of a tool has to do with its ability to measure the same characteristic, in the same field or domain. This research tool was consistent, since the questions asked about a particular soft skill were 
kept under the same focus, homogeneity and coherence within the same perspective.

The comparison between the different profiles interviewed is another desirable characteristic that the model offers, in addition to allowing necessary adjustments to be made-the investment on people, resources and curricular adaptations to reach the index desired by the user. The relevance of these analyzes, as well as of the simulations, is supported by the orientation of improvements and improvements in the Engineering courses with regard to soft skills.

In addition, the proposed model presents a powerful structure for data collection, allowing its application in the comparison between the reality of the Engineering job market (Campos et al., 2020b) and the perception of graduates, students and teachers. The application of this model also includes intermediate results from all 6 thematic groups, that is, the soft skills listed as important for the training of Engineering professionals.

In a Nutshell, this is an easy-to-use model, in which only input data needs to be changed for each group (soft skills) or in isolation, and can be used for the investigation of the need for improvements in courses, curricular guidelines and training practices for Engineering professionals.

\section{Conflicts of Interest}

The authors declare no conflicts of interest regarding the publication of this paper.

\section{References}

Ahn, J.-W. et al. (2019). Blockchain for Open Scientific Research. U.S. Patent Application, n. $10 / 320,574$

Arruda, D. M. et al. (2019). Análise comparativa de ferramentas computacionais para modelagem de lógica fuzzy. X Simpósio de Excelência em Gestão e Tecnologia, Resende.

Bonventi Jr, W. A. L. D. E. M. A. R., \& Costa, A. H. R. (2000). Comparação entre métodos de definição de conjuntos nebulosos de cores para classificação de pixels. International Joint Conference Iberamia, 19-22.

https://www.researchgate.net/profile/Waldemar_Bonventi/publication/228558224_Compar acao_entre_metodos_de_definicao_de_conjuntos_nebulosos_de_cores_para_a_classificaca o_de_pixels/links/00b4953b0bf05a7ac0000000.pdf

Boutros, P. C., \& Chen, H. (2011). Venn Diagram: A Package for the Generation of Highly Customizable Venn and Euler Diagrams in R. BMC Bioinformatics, 12, 35. https://doi.org/10.1186/1471-2105-12-35

Brayan, L. A., \& Brayan, E. A. (1997). Programmable Controllers: Theory and Implementation (2. ed., 1035 p). Atlanta, GA: Industrial Text.

Caiado, R. G. G., Scavarda, L. F., Gavião, L. O., Ivson, P., de Mattos Nascimento, D. L., \& Garza-Reyes, J. A. (2021). A Fuzzy Rule-Based Industry 4.0 Maturity Model for Operations and Supply Chain Management. International Journal of Production Economics, 231, Article ID: 107883. https://doi.org/10.1016/j.ijpe.2020.107883

Campos Filho, P. (2004). Método de apoio à decisão na verificação da sustentabilidade de uma unidade de conservação, usando lógica Fuzzy. 211 f. Tese (Doutorado em Engen- 
haria de Produção), Florianópolis: Pós-Graduação em Engenharia de Produção, Universidade Federal de Santa Catarina.

Campos, D. B. (2019). Desenvolvimento de um Modelo Diagnóstico de Formação de Competências Socioemocionais para Cursos de Engenharia. 222 f. Tese (Doutorado) Curso de Ensino de Ciência e Tecnologia, Ponta Grossa: Pós-graduação em Ensino de Ciência e Tecnologia, Universidade Tecnológica Federal do Paraná.

Campos, D. B., de Resende, L. M. M., \& Fagundes, A. B. (2020a). The Importance of Soft Skills for the Engineering. Creative Education, 11, 1504.

https://doi.org/10.4236/ce.2020.118109

Campos, D. B., Resende, L. M. M., \& Fagundes, A. B. (2020b). Soft Skills by Engineering Employers. Creative Education, 11, 2133. https://doi.org/10.4236/ce.2020.1110155

Campos, E. A. R. et al. (2018). Construction and Qualitative Assessment of a Bibliographic Portfolio Using the Methodology Methodi Ordinatio. Scientometrics, 116, 815842. https://doi.org/10.1007/s11192-018-2798-3

Candido, R. et al. (2007). Método Delphi-uma ferramenta para uso em Microempresas de Base Tecnológica. Revista da FAE, 10, 157-164.

Casner-Lotto, J., \& Barrington, L. (2006). Are They Really Ready to Work? Employers' Perspectives on the Basic Knowledge and Applied Skills of New Entrants to the 21st Century US Workforce.

Cavalcanti, M. T. et al. (2013). Aplicação da lógica fuzzy na análise sensorial de pão de forma enriquecido. Revista Brasileira de Engenharia Agrícola e AmbientalAgriambi, 17, 208-215. https://doi.org/10.1590/S1415-43662013000200012

Chakraverty, S., \& Behera, D. (2013). Fuzzy System of Linear Equations with Crisp Coefficients. Journal of Intelligent \& Fuzzy Systems, 25, 201-207. https://doi.org/10.3233/IFS-2012-0627

Fadzil, H. M., \& Saat, R. M. (2019). Development of Instrument in Assessing Students' Science Manipulative Skills. Malaysian Online Journal of Educational Sciences, 7, 47-57.

Fagundes, A. B. (2015). Modelagem Fuzzy para avaliação de desempenho ambiental do gerenciamento de resíduos sólidos industriais. 214 f. Tese (Doutorado em Tecnologia), Curitiba: Universidade Tecnológica Federal do Paraná.

Giovinazzo, R. A. (2001). Modelo de aplicação da metodologia Delphi pela internet: Vantagens e ressalvas. Administração on line, 2, 1-11.

Gondim, S. M. G., Borges-Andrade, J. E., \& Bastos, A. V. B. (2017). Psicologia do Trabalho e das Organizações: Produção científica e desafios metodológicos. Revista Psicologia em Pesquisa, 4, 84-99.

Listone, H. A., \& Turoff, M. (2002). The Delphi Method: Techniques and Applications, College of Computing Sciences (618 p.). Newark, NJ: New Jersey Institute of Technology.

Martino, J. P. (1993). Technological Forecasting for Decision Making (3rd ed., 462 p.). New York: McGraw-Hill Inc.

Martins, E. T., \& Martins, I. T. (2016). A lógica Fuzzi na operacionalização de conhecimentos em interação de tarefas Humano-Computador em máquinas complexas: A aprendizagem em conjuntos de significância. TEXTOS. Revista Internacional de Aprendizaje y Cibersociedad, 19, 153-177. https://doi.org/10.37467/gka-revciber.v19.874

OECD (2015). Skills for Social Progress: The Power of Social and Emotional Skills. OECD Skills Studies, Paris: OECD Publishing.

OECD (2016a). Skills Matter: Further Results from the Survey of Adult Skills. OECD Skills Studies, Paris: OECD Publishing. 
OECD (2016b). The Survey of Adult Skills: Reader's Companion (2nd ed.). OECD Skills Studies, Paris: OECD Publishing.

Pagani, R. N., Kovaleski, J. L., \& Resende, L. M. (2015). Methodi Ordinatio: A Proposed Methodology to Select and Rank Relevant Scientific Papers Encompassing the Impact Factor, Number of Citation, and Year of Publication. Scientometrics, 105, 2109-2135. https://doi.org/10.1007/s11192-015-1744-X

Souza, A. C., Alexandre, N. M. C., \& Guirardello, E. B. (2017). Propriedades psicométricas na avaliação de instrumentos: Avaliação da confiabilidade e da validade. Epidemiologia e Serviços de Saúde, 26, 649-659. https://doi.org/10.5123/S1679-49742017000300022

Takáč, Z. (2014). Aggregation of Fuzzy Truth Values. Information Sciences, 271, 1-13. https://doi.org/10.1016/j.ins.2014.02.116

Toledo, O. M., \& Cosenza, C. A. N. (2004). Metodologia de avaliação de desempenho baseada em lógica fuzzy. Congresso Brasileiro de Ensino de Engenharia Cobenge. https://www.researchgate.net/profile/Olga_Toledo/publication/267230451_METODOL OGIA_DE_AVALIACAO_DE_DESEMPENHO_BASEADA_EM_LOGICA_FUZZY/li nks/56a8c1ea08ae860e02577ab5.pdf

Umanailo, M. C. B. et al. (2019). Utilization of Qualitative Methods in Research Universities. Education Science, 21, 2076-2081.

Vieira, K. M., \& Dalmoro, M. (2008). Dilemas na construção de escala de likert: O número de itens e a disposição influenciam nos resultados. Encontro Nacional da Associação Nacional de Pós-Graduação e Pesquisa em Administração, Rio de Janeiro, Vol. 32, 20082020.

Williamson, B., \& Piattoeva, N. (2019). Objectivity as Standardization in Data-Scientific Education Policy, Technology and Governance. Learning, Media and Technology, 44, 64-76. https://doi.org/10.1080/17439884.2018.1556215

Wright, J. T. C. et al. (2000). Delphi: Uma ferramenta de apoio ao planejamento prospectivo. Caderno de Pesquisas em Administração, 1, 54-65.

Zupic, I., \& Čater, T. (2015). Bibliometric Methods in Management and Organization. Organizational Research Methods, 18, 429-472. https://doi.org/10.1177/1094428114562629 


\section{Appendices}

Appendix 1. Questionnaire for Organizational Psychology professionals for FuzzyTECH Software calibration.

Consider that, to hire an Engineer in your organization, soft skills are evaluated using this query. Mark, for each of these skills, according to the corresponding scale, the minimum expected for a potential candidate to be able to be part of your organization.

How much "Find Solutions using multidisciplinary knowledge" using impacts "Problem Solving"

How much "Use knowledge, data and facts" impacts "Problem Solving"

How much "Problem Solving" impacts "Critical Thinking"

How much "Ability to solve problems in a pacific manner" impacts "Open Mind"

How much "Openness to suggestions, new

ideas and contrary opinions" impacts "Open Mind"

How much "Open Mind" impacts "Critical Thinking”

How "Critical Thinking" impacts "Results"

How much "Ability to talk in public" impacts "Oral Communication"

How much "Ability to present ideas clearly during a conversation" impacts "Oral Communication"

How much "Oral Communication" impacts "Communication"

How much "Ability to write complex reports and documents with clarity" impacts "Written Communication"

How much "Having an understandable handwriting and good domain of grammar and rules of the native language grammar" impacts "Written Communication"

How much "Written Communication" impacts "Communication"

How much "Ability to listen to the interlocutor and wait to speak" impacts

"Active Listening"

How much "Think in an articulate manner, with clear and efficient ideas" impacts "Active Listening"

How "Active Listening" impacts

"Communication"

How much "Ability to interpret texts, using all the data within contained" impacts "Reading"

How much "Reading" impacts "Communication"

2

0

2




\section{Continued}

How much "Ability to read, speak and write in a language other than the native language" impacts "Foreign Language"

How much "Foreign Language" impacts "Communication"

How much "Communication" impacts "Results"

How much "Ability to work in collaboration with individuals from different cultures, genders, religions and lifestyles" impacts "Multiculturalism"

How much "Multiculturalism" impacts "Team Work"

How much "Creation of collaborative relationships with colleagues and clients" impacts "Networking"

How much "Networking" impacts "Team Work"

How much "Ability to negotiate and manage conflicts with diverse teams" impacts "Leadership"

How much "Encourage others to develop their strengths to achieve a common goal" impacts "Leadership"

How much "Ability to use interpersonal

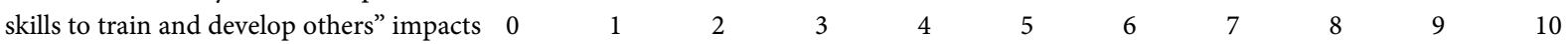
"Leadership"

How much "Leadership" impacts "Team Work"

How much "Team Work" impacts "Results"

How much "Demonstrate Integrity and ethical behavior" impacts "Ethics"

How much "Commitment with work" impacts "Professionalism"

How much "Professionalism" impacts "Ethic Perspective"

How much "Act responsibly according to the society's needs" impacts "Ethic Perspective"

How much que "Social Responsibility" impacts "Ethic Perspective"

How much "Ethic Perspective" impacts "Results"

How much "Ability to Learn with the own mistakes" impacts "Control of emotions"

How much "Possessing self-control" impacts "Control of emotions"

(2)

0

(2)




\section{Continued}

\begin{tabular}{|c|c|c|c|c|c|c|c|c|c|c|c|}
\hline $\begin{array}{l}\text { How much "Control of Emotions" impacts } \\
\text { "Emotional Intelligence" }\end{array}$ & 0 & 1 & 2 & 3 & 4 & 5 & 6 & 7 & 8 & 9 & 10 \\
\hline $\begin{array}{l}\text { How much "Being persistent" impacts } \\
\text { "Motivation" }\end{array}$ & 0 & 1 & 2 & 3 & 4 & 5 & 6 & 7 & 8 & 9 & 10 \\
\hline $\begin{array}{l}\text { How much "Having passion for the goals" } \\
\text { impacts "Motivation" }\end{array}$ & 0 & 1 & 2 & 3 & 4 & 5 & 6 & 7 & 8 & 9 & 10 \\
\hline $\begin{array}{l}\text { How much "Possess self-esteem, optimism } \\
\text { and confidence" impacts "Motivation" }\end{array}$ & 0 & 1 & 2 & 3 & 4 & 5 & 6 & 7 & 8 & 9 & 10 \\
\hline $\begin{array}{l}\text { How much "Motivation" impacts } \\
\text { "Emotional Intelligence" }\end{array}$ & 0 & 1 & 2 & 3 & 4 & 5 & 6 & 7 & 8 & 9 & 10 \\
\hline $\begin{array}{l}\text { How much "Ability to continuously } \\
\text { acquire new knowledge and skills" impacts } \\
\text { "Lifelong learning" }\end{array}$ & 0 & 1 & 2 & 3 & 4 & 5 & 6 & 7 & 8 & 9 & 10 \\
\hline $\begin{array}{l}\text { How much "Lifelong Learning" impacts } \\
\text { "Emotional Intelligence" }\end{array}$ & 0 & 1 & 2 & 3 & 4 & 5 & 6 & 7 & 8 & 9 & 10 \\
\hline $\begin{array}{l}\text { How much "Ability to evaluate the own } \\
\text { needs for improvement" impacts } \\
\text { "Self-Direction" }\end{array}$ & 0 & 1 & 2 & 3 & 4 & 5 & 6 & 7 & 8 & 9 & 10 \\
\hline $\begin{array}{l}\text { How much "Self-Direction" impacts } \\
\text { "Emotional Intelligence" }\end{array}$ & 0 & 1 & 2 & 3 & 4 & 5 & 6 & 7 & 8 & 9 & 10 \\
\hline $\begin{array}{l}\text { How much "Emotional Intelligence" } \\
\text { impacts "Results" }\end{array}$ & 0 & 1 & 2 & 3 & 4 & 5 & 6 & 7 & 8 & 9 & 10 \\
\hline $\begin{array}{l}\text { How much "Ability to bring new ideas" } \\
\text { impact "Creativity" }\end{array}$ & 0 & 1 & 2 & 3 & 4 & 5 & 6 & 7 & 8 & 9 & 10 \\
\hline $\begin{array}{l}\text { How much "Creativity" impacts "Creative } \\
\text { Thinking" }\end{array}$ & 0 & 1 & 2 & 3 & 4 & 5 & 6 & 7 & 8 & 9 & 10 \\
\hline $\begin{array}{l}\text { How much "Ability to put new ideas into } \\
\text { practice" impacts "Innovation" }\end{array}$ & 0 & 1 & 2 & 3 & 4 & 5 & 6 & 7 & 8 & 9 & 10 \\
\hline $\begin{array}{l}\text { How much "Innovation" impacts "Creative } \\
\text { Thinking" }\end{array}$ & 0 & 1 & 2 & 3 & 4 & 5 & 6 & 7 & 8 & 9 & 10 \\
\hline $\begin{array}{l}\text { How much "Creative Thinking" impacts } \\
\text { "Results" }\end{array}$ & 0 & 1 & 2 & 3 & 4 & 5 & 6 & 7 & 8 & 9 & 10 \\
\hline
\end{tabular}

Appendix 2. Questionnaire about the students' perception on the soft skills development at their attended courses.

Check the scale corresponding to your perception of the development of soft skills in the courses you attended.

Questions about Problem Solving

D1-Find solutions using multidisciplinary knowledge

D2-Use knowledge, data and facts to solve problems at work

Questions about Open Mind

D3-Ability to solve problems in a pacific manner

D4-Openness to suggestions, new ideas and contrary opinions

Questions about Verbal Communication

D5-Ability to talk in public

0

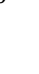

$\begin{array}{llllllllll}1 & 2 & 3 & 4 & 5 & 6 & 7 & 8 & 9 & 10\end{array}$

0

$\begin{array}{lllll}1 & 2 & 3 & 4 & 5\end{array}$

$\begin{array}{lllll}6 & 7 & 8 & 9 & 10\end{array}$




\section{Continued}

D6-Ability to present ideas clearly

during a conversation

0

Questions about Written Communication

D7-Ability to write complex reports

and documents with clarity

D8-Having an understandable handwriting and good domain of grammar and rules of the native language

Questions about Active Listening

D9-Ability to listen the interlocutor and wait to speak

D10-Think in an articulate manner, with clear and efficient ideas

Question about Reading

D11-Ability to interpret complex texts, being able to utilize all the data 0 contained in them

Question about Foreign Language

D12-Ability to read, speak and write in a language other than the native language

Question about Multiculturalism

D13-Ability to work in

collaboration with individuals from different cultures, genders, religions and lifestyles

Question about Networking

D14-Creation of collaborative relationships with colleagues and clients

Questions about Leadership

D15-Ability to negotiate and manage conflicts with diverse teams

D16-Encourage others to develop their strengths to achieve a common 0 goal

D17-Ability to use interpersonal skills to train and develop others

Question about Ethics

D18-Demonstrate Integrity and ethical behavior

Question about Professionalism

D19-Commitment with work

Question about Social Responsibility 


\section{Continued}

\begin{tabular}{|c|c|c|c|c|c|c|c|c|c|c|c|}
\hline $\begin{array}{l}20-\text { Act responsibly according to the } \\
\text { society's needs }\end{array}$ & 0 & 1 & 2 & 3 & 4 & 5 & 6 & 7 & 8 & 9 & 10 \\
\hline \multicolumn{12}{|l|}{ Questions about Control of Emotions } \\
\hline $\begin{array}{l}\text { D21-Ability to Learn with the own } \\
\text { mistakes. }\end{array}$ & 0 & 1 & 2 & 3 & 4 & 5 & 6 & 7 & 8 & 9 & 10 \\
\hline D22-Possessing self-control & 0 & 1 & 2 & 3 & 4 & 5 & 6 & 7 & 8 & 9 & 10 \\
\hline \multicolumn{12}{|l|}{ Questions about Motivation } \\
\hline D23-Being persistent & 0 & 1 & 2 & 3 & 4 & 5 & 6 & 7 & 8 & 9 & 10 \\
\hline D24-Having passion for the goals & 0 & 1 & 2 & 3 & 4 & 5 & 6 & 7 & 8 & 9 & 10 \\
\hline $\begin{array}{l}\text { D25-Possessing self-esteem, } \\
\text { optimism and confidence }\end{array}$ & 0 & 1 & 2 & 3 & 4 & 5 & 6 & 7 & 8 & 9 & 10 \\
\hline \multicolumn{12}{|l|}{ Question about Lifelong Learning } \\
\hline $\begin{array}{l}\text { D26-Ability to continuously acquire } \\
\text { new knowledge and skills }\end{array}$ & 0 & 1 & 2 & 3 & 4 & 5 & 6 & 7 & 8 & 9 & 10 \\
\hline \multicolumn{12}{|l|}{ Question about Self-Direction } \\
\hline $\begin{array}{l}\text { D27-Ability to evaluate the own } \\
\text { needs for improvement }\end{array}$ & 0 & 1 & 2 & 3 & 4 & 5 & 6 & 7 & 8 & 9 & 10 \\
\hline \multicolumn{12}{|l|}{ Question about Creativity } \\
\hline D28-Ability to bring new ideas & 0 & 1 & 2 & 3 & 4 & 5 & 6 & 7 & 8 & 9 & 10 \\
\hline \multicolumn{12}{|l|}{ Question about Innovation } \\
\hline $\begin{array}{l}\text { D29-Ability to put new ideas into } \\
\text { practice }\end{array}$ & 0 & 1 & 2 & 3 & 4 & 5 & 6 & 7 & 8 & 9 & 10 \\
\hline
\end{tabular}

Source: Campos, 2019.

Appendix 3. Questionnaire about the graduate students' perception about the soft skills learned at university.

Check the scale corresponding to your perception regarding the soft skills you learned during university

Questions about Problem Solving

D1-Find solutions using multidisciplinary knowledge

D2-Use knowledge, data and facts to solve problems at work

Questions about Open Mind

D3-Ability to solve problems in a pacific manner

D4-Openness to suggestions, new ideas and contrary opinions

Questions about Verbal Communication

D5-Ability to talk in public

D6-Ability to present ideas clearly during a conversation 0 2 $3 \quad 4$

Questions about Written Communication

D7-Ability to write complex reports and documents with clarity 


\section{Continued}

D8-Having an understandable handwriting and good domain of grammar and rules of the native language

Questions about Active Listening

D9-Ability to listen the interlocutor and wait to speak

D10-Think in an articulate manner, with clear and efficient ideas

Question about Reading

D11-Ability to interpret complex texts, being able to utilize all the data contained in them

Question about Foreign Language

D12-Ability to read, speak and write in a language other than the native language

Question about Multiculturalism

D13-Ability to work in collaboration with individuals from different cultures, genders, religions and lifestyles

Question about Networking

D14-Creation of collaborative relationships with colleagues and clients

Questions about Leadership

D15-Ability to negotiate and manage conflicts with diverse teams

D16-Encourage others to develop their strengths to achieve a common 0 goal

D17-Ability to use interpersonal skills to train and develop others

Question about Ethics

D18-Demonstrate Integrity and ethical behavior

12

3

$(2$

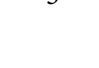

$\left(\frac{10}{2}\right.$

$\begin{array}{llll}7 & 8 & 9 & 10\end{array}$

10 


\section{Continued}

Questions about Motivation

\begin{tabular}{|c|c|c|c|c|c|c|c|c|c|c|}
\hline D23-Being persistent & 0 & 1 & 2 & 3 & 4 & 5 & 6 & 7 & 8 & 9 \\
\hline D24-Having passion for the goals & 0 & 1 & 2 & 3 & 4 & 5 & 6 & 7 & 8 & 9 \\
\hline $\begin{array}{l}\text { D25-Possessing self-esteem, } \\
\text { optimism and confidence }\end{array}$ & 0 & 1 & 2 & 3 & 4 & 5 & 6 & 7 & 8 & 9 \\
\hline
\end{tabular}

Question about Lifelong Learning

D26-Ability to continuously acquire new knowledge and skills

Question about Self-Direction

D27-Ability to evaluate the own needs for improvement

$\begin{array}{lllllllllll}0 & 1 & 2 & 3 & 4 & 5 & 6 & 7 & 8 & 9 & 10\end{array}$

Question about Creativity

D28-Ability to bring new ideas

0

Question about Innovation

D29-Ability to put new ideas into practice

Source: Campos, 2019.

Appendix 4. Questionnaire about the professor's perception about the development of soft skills in their courses.

Mark on the corresponding scale your perception of how much the (your course's name)

contributes to the development of the students' soft skills

Questions about Problem Solving

D1-Find solutions using

multidisciplinary knowledge

D2-Use knowledge, data and facts

to solve problems at work

0

Questions about Open Mind

D3-Ability to solve problems in a pacific manner

D4-Openness to suggestions, new ideas and contrary opinions

Questions about Verbal Communication

D5-Ability to talk in public

D6-Ability to present ideas clearly during a conversation

Questions about Written Communication

D7-Ability to write complex reports and documents with clarity

D8-Having an understandable handwriting and good domain of grammar and rules of the native language

Questions about Active Listening 


\section{Continued}

D9-Ability to listen the interlocutor

and wait to speak

D10-Think in an articulate manner,

with clear and efficient ideas

Question about Reading

D11-Ability to interpret complex

texts, being able to utilize all the data

contained in them

Question about Foreign Language

D12-Ability to read, speak and

write in a language other than the

native language

Question about Multiculturalism

D13-Ability to work in

collaboration with individuals from

different cultures, genders, religions

and lifestyles

Question about Networking

D14-Creation of collaborative

relationships with colleagues and

clients

Questions about Leadership

D15-Ability to negotiate and manage conflicts with diverse teams

D16-Encourage others to develop

their strengths to achieve a common 0 goal

D17-Ability to use interpersonal skills to train and develop others

Question about Ethics

D18-Demonstrate Integrity and ethical behavior

Question about Professionalism

D19-Commitment with work

Question about Social Responsibility

20-Act responsibly according to the society's needs

Questions about Control of Emotions

D21-Ability to Learn with the own mistakes.

D22-Possessing self-control

3

$2 \quad 3$

\section{5}

6

$\begin{array}{llll}7 & 8 & 9 & 10 \\ 7 & 8 & 9 & 10\end{array}$

10

10 


\section{Continued}

\begin{tabular}{|c|c|c|c|c|c|c|c|c|c|c|c|}
\hline $\begin{array}{l}\text { D25-Possessing self-esteem, } \\
\text { optimism and confidence }\end{array}$ & 0 & 1 & 2 & 3 & 4 & 5 & 6 & 7 & 8 & 9 & 10 \\
\hline \multicolumn{12}{|l|}{ Question about Lifelong Learning } \\
\hline $\begin{array}{l}\text { D26-Ability to continuously } \\
\text { acquire new knowledge and skills }\end{array}$ & 0 & 1 & 2 & 3 & 4 & 5 & 6 & 7 & 8 & 9 & 10 \\
\hline \multicolumn{12}{|l|}{ Question about Self-Direction } \\
\hline $\begin{array}{l}\text { D27-Ability to evaluate the own } \\
\text { needs for improvement }\end{array}$ & 0 & 1 & 2 & 3 & 4 & 5 & 6 & 7 & 8 & 9 & 10 \\
\hline \multicolumn{12}{|l|}{ Question about Creativity } \\
\hline D28-Ability to bring new ideas & 0 & 1 & 2 & 3 & 4 & 5 & 6 & 7 & 8 & 9 & 10 \\
\hline \multicolumn{12}{|l|}{ Question about Innovation } \\
\hline $\begin{array}{l}\text { D29-Ability to put new ideas into } \\
\text { practice }\end{array}$ & 0 & 1 & 2 & 3 & 4 & 5 & 6 & 7 & 8 & 9 & 10 \\
\hline
\end{tabular}

Source: Campos, 2019.

Appendix 5. Questionnaire about the minimum requirement of soft skills from Engineering employers for Engineer's hiring.

Consider that, to hire an Engineer in your organization, soft skills are evaluated using this query. Mark, for each of these skills, according to the corresponding scale, the minimum expected for a potential candidate to be able to be part of your organization.

Questions about Problem Solving

D1-Find solutions using multidisciplinary knowledge

D2-Use knowledge, data and facts

to solve problems at work

Questions about Open Mind

D3-Ability to solve problems in a pacific manner

D4-Openness to suggestions, new ideas and contrary opinions

Questions about Verbal Communication

D5-Ability to talk in public

D6-Ability to present ideas clearly

during a conversation

Questions about Written Communication

D7-Ability to write complex reports

and documents with clarity

D8-Having an understandable handwriting and good domain of grammar and rules of the native language

Questions about Active Listening

D9-Ability to listen the interlocutor and wait to speak

D10-Think in an articulate manner, with clear and efficient ideas

2




\section{Continued}

Question about Reading

D11-Ability to interpret complex texts, being able to utilize all the data 0 contained in them

Question about Foreign Language

D12-Ability to read, speak and write in a language other than the native language

Question about Multiculturalism

D13-Ability to work in

collaboration with individuals from different cultures, genders, religions and lifestyles

Question about Networking

D14-Creation of collaborative relationships with colleagues and clients

Questions about Leadership

D15-Ability to negotiate and manage conflicts with diverse teams

D16-Encourage others to develop their strengths to achieve a common 0 goal

D17-Ability to use interpersonal skills to train and develop others

Question about Ethics

D18-Demonstrate Integrity and ethical behavior

Question about Professionalism

D19-Commitment with work

Question about Social Responsibility

D20-Act responsibly according to the society's needs

Questions about Control of Emotions

D21-Ability to Learn with the own mistakes.

D22-Possessing self-control

0

Questions about Motivation

D23-Being persistent

D24-Having passion for the goals

D25-Possessing self-esteem,

optimism and confidence

Question about Lifelong Learning 


\section{Continued}

\begin{tabular}{|c|c|c|c|c|c|c|c|c|c|c|c|}
\hline $\begin{array}{l}\text { D26-Ability to continuously } \\
\text { acquire new knowledge and skills }\end{array}$ & 0 & 1 & 2 & 3 & 4 & 5 & 6 & 7 & 8 & 9 & 10 \\
\hline \multicolumn{12}{|l|}{ Question about Self-Direction } \\
\hline $\begin{array}{l}\text { D27-Ability to evaluate the own } \\
\text { needs for improvement }\end{array}$ & 0 & 1 & 2 & 3 & 4 & 5 & 6 & 7 & 8 & 9 & 10 \\
\hline \multicolumn{12}{|l|}{ Question about Creativity } \\
\hline D28-Ability to bring new ideas & 0 & 1 & 2 & 3 & 4 & 5 & 6 & 7 & 8 & 9 & 10 \\
\hline \multicolumn{12}{|l|}{ Question about Innovation } \\
\hline $\begin{array}{l}\text { D29-Ability to put new ideas into } \\
\text { practice }\end{array}$ & 0 & 1 & 2 & 3 & 4 & 5 & 6 & 7 & 8 & 9 & 10 \\
\hline
\end{tabular}

Source: Campos, 2019.

Appendix 6. Questionnaire about the employers' perception about their recently-hired collaborators' soft skills.

Check the scale corresponding to your perception regarding the soft skills of the recently-hired Engineers in your organization (up to 1 year experience)

Questions about Problem Solving

D1-Find solutions using multidisciplinary knowledge

D2-Use knowledge, data and facts

to solve problems at work

Questions about Open Mind

D3-Ability to solve problems in a pacific manner

D4-Openness to suggestions, new ideas and contrary opinions

Questions about Verbal Communication

D5-Ability to talk in public

D6-Ability to present ideas clearly

during a conversation

0

1

1

Questions about Written Communication

D7-Ability to write complex reports and documents with clarity

D8-Having an understandable handwriting and good domain of grammar and rules of the native language

Questions about Active Listening

D9-Ability to listen the interlocutor and wait to speak

D10-Think in an articulate manner, with clear and efficient ideas

Question about Reading

D11-Ability to interpret complex texts, being able to utilize all the data contained in them 


\section{Continued}

Question about Foreign Language

D12-Ability to read, speak and write in a language other than the native language

Question about Multiculturalism

D13-Ability to work in

collaboration with individuals from different cultures, genders, religions and lifestyles

Question about Networking

D14-Creation of collaborative relationships with colleagues and clients

Questions about Leadership

D15-Ability to negotiate and manage conflicts with diverse teams

D16-Encourage others to develop their strengths to achieve a common 0 goal

D17-Ability to use interpersonal skills to train and develop others

Question about Ethics

D18-Demonstrate Integrity and ethical behavior

Question about Professionalism

D19-Commitment with work

Question about Social Responsibility

20-Act responsibly according to the society's needs

Questions about Control of Emotions

D21-Ability to Learn with the own mistakes.

D22-Possessing self-control

Questions about Motivation

D23-Being persistent

D24-Having passion for the goals

D25-Possessing self-esteem, optimism and confidence

Question about Lifelong Learning

D26-Ability to continuously acquire new knowledge and skills

Question about Self-Direction

D27-Ability to evaluate the own needs for improvement

1

2

3

4

5

6

7

8

9

10 


\section{Continued}

Question about Creativity

D28-Ability to bring new idea

0

$1 \quad 2 \quad 3$

45

6

7

8

9

10

Question about Innovation

D29-Ability to put new ideas into practice

$0 \quad 1$

$\begin{array}{llllllll}3 & 4 & 5 & 6 & 7 & 8 & 9 & 10\end{array}$

Source: Campos, 2019.

Appendix 7. 335 articles related to the research scope. The articles in bold are the ones ordered by the Index Ordinatio. The JEE articles are also shown in bold at the end of the table.

Article
"Liberal Education Has Failed": Reading Like an Engineer in 1960s America.
Rounding-up the industrial engineering educational profile with adaptive
soft skills framed by a cultural competency approach in an
industry-university partnership
"Continue The Story" A Simple Game, Profound Implications For Knowledge
Management

\section{"Ningen Ryoku": the Japanese Way in Inculcating Human Skill into Engineering Education}

"Necessary to engineers of the new generation": what is important for engineers to know?

"The best and the brightest"?

A blended approach to course design and pedagogy to impart soft skills: An IT company's experiences from software engineering course

A case study on project led education in engineering: students' and teachers' perceptions.

"Liberal Education Has Failed": Reading Like an Engineer in 1960s America.

A Competence-Based Approach to Sustainable Innovation Teaching:

Experiences Within a New Engineering Program.

A differential evolution algorithm to solve multi-skilled project portfolio scheduling problems

A Global Human Potential Movement and a Rebirth of Humanistic Psychology.

A good answer to (perhaps) not such very good questions.

A method for designing automatic assessment systems based on teachers reasoning for evaluating subjective engineering student's competences

A new engineering education model for Malaysia

A Notional Model of Creation, Maintenance, and Enrichment of Human Capital

A pressure cooker-Coaching framework for teaching soft skills in an engineering master's programme

A Problem Based Learning Framework to Assess and Develop Soft Skills in a Linear Programming Course.

A Skills Audit.

Journal Year

Technology \& Culture

2009

Proceedings of the ASEE Annual Conference \&

Exposition

Conference proceedings of eLearning and Software

for Education

2013

International Conference On Teaching And Learning

In Higher Education In Conjunction With Regional

Conference on Engineering Education And Research

In Higher Education

Engineering Studies

2015

TIDSSKRIFT FOR SAMFUNNSFORSKNING

Students' Technology Symposium

European Journal of Engineering Education

Technology \& Culture

Journal of Mechanical Design

International Journal of Advanced Manufacturing

Technology

Humanistic Psychologist

Engineering Studies

2014 9th Iberian Conference on Information Systems and Technologies

International Journal of Engineering Education

Procedia Manufacturing

2015

2015 IEEE Global Engineering Education Conference

Proceedings of the ASEE Annual Conference \& Exposition

Training \& Development Journal

1980 


\section{Continued}

A Study of Alumni Feedback on Outcome based Education in the Faculty of Engineering \&amp; Built Environment, Universiti Kebangsaan Malaysia

A Systematic Approach to Engineering Ethics Education

A world first in collaborative cross-discipline agriculture and engineering education project

ABET 2000: what are the most important criteria to the supervisors of new engineering undergraduates?

AC 2011-1117: Liberal Learning Revisited: A Historical Examination Of The Underlying Reasons, Frustrations, And Continued Prospects For Engineering And Liberal Arts Integration

Acclimating International Graduate Students to Professional Engineering Ethics

Active learning strategies: An illustrative approach to bring out better learning outcomes from Science, Technology, Engineering and Mathematics (STEM) students

Adapting Teaching Strategies to Global and Analytic Learning Styles by Real World Engineering Projects

Adoption of new subjects to improve the formation of future engineer

Advancing global capacity for engineering education research: relating research to practice, policy and industry.

ADVEISOR- Learning By Doing- The Experience Of Soft Skills In An Engineering Project Created And Accomplished By Students.

An analysis of the curriculum for water supply and drainage, science and engineering, based on CCDIO

An approach for harmonizing engineering and science education with humaneness

An approach to assess knowledge and skills in risk management through project-based learning

An approach to developing independent learning and non-technical skills amongst final year mining engineering students.

An evaluation of the use of computer supported peer review for developing higher-level skills

Analysis of Non Technical Skills for ICT Profiles

Answers Are Not Written At The End Of The Book: Non-Technical Content Of Engineering Education

Applied System and Control Sciences to Social Systems: Globalization Age Paradigms

Assessing oral presentations and writing skills

Assessing soft and higher order thinking skills among Students using a rubric and Progressive Reflection

Assessing technology incubator programs in the science park: the good, the bad and the ugly

Assessment of soft-skills for student outcomes using engineering courses
Procedia-Social and Behavioral Sciences

Science and Engineering Ethics

International Journal of Mechanical Engineering Education

age

1998

American Society for Engineering Education

Science and Engineering Ethics

Journal of Emerging Technologies in Learning

2014 IEEE Global Engineering Education Conference (EDUCON)

29th Annual Frontiers in Education Conference: "Designing the Future of Science and Engineering Education"

European Journal of Engineering Education

EDULEARN13 Proceedings

Applied Mechanics and Materials

Science and Engineering Ethics

Journal of Biomechanical Engineering

European Journal of Engineering Education

Computers \& Education

5th Iberian Conference on Information Systems and Technologies (CISTI), Santiago de Compostela

Fire Engineering

IFAC Proceedings Volumes

Proceedings-2004 International Professional Communication Conference

MOOC Innovation and Technology in Education

American Society for Engineering Education 


\section{Continued}

Between general culture and challenges of engineering businesses: the diversity of teaching in the humanities and social sciences at the Ecole Centrale de Lyon

Booknotes.

Brains of Steel: Mind Melding with Materials

Bringing the Human Factor to Software Engineering.

Broadening Engineering Education: Bringing the Community In Commentary on "Social Responsibility in French Engineering Education: A Historical and Sociological Analysis"

\section{Building a Bridge Between Engineering and the Humanities.}

Building ethics and project management into engineering technology programs

Building Excellence In Engineering Education In India

Can disciplinary integration promote students' lifelong learning attitudes and skills in project-based engineering courses?

Capabilities for a cosmopolitan citizenship in higher education The experience of the Technical University of Valencia

Capstone engineering design experience: Opportunities to develop and implement skills that work for real people doing real jobs

Care Ethics in Engineering Education Undergraduate Student Perceptions of Responsibility

\section{Challenges before engineering education-Role of humanities and social sciences}

Chemical Engineering students soft-skills in Integrated Project (IP) Part 4

Closing the Gap Between College Entry and Employment.

Coaches safety orientation and training skills program

Co-creating liberal studies in engineering program(s) - a perspective from Ethnic Studies, Women's \& Gender Studies, and Science \& Technology Studies.

Cognitive And Emotional Variables In University Students

Cognitive Readiness and the Challenge of Institutionalizing the "New" Versus "News";

College Chinese and humanities education

Comments on “On 'Bettering Humanity' in Science and Engineering Education”.

Communication skills to develop trusting relationships on global virtual engineering capstone teams.

Comparison of the impact of two research experiences for undergraduate programs on preparing students for global workforces

\section{Competencies And Innovations Labs: Humanities In Engineers' High-Education}

Competency-based on-the-job training for aviation maintenance and inspection - A human factors approach
Shst 2013-Upec: Sciences Humaines En Sciences Et

Techniques-Les Sciences Humaines Dans Les

Parcours Scientifiques Et Techniques

Professionnalisants: Quelles Finalites Et Quelles

Modalites Pratiques?

European Journal of Engineering Education

1999

International Journal of Engineering Education

2001

IEEE Software

Science and Engineering Ethics

Chronicle of Higher Education

age

Proceedings Of 2015 IEEE Global Engineering Education Conference (EDUCON)

The International Journal of Engineering Education

Procedia-Social and Behavioral Sciences

2010

SPE Annual Technical Conference and Exhibition

2012 Frontiers In Education Conference (FIE)

Pertanika Journal of Social Science and Humanities

2015 IEEE 7th International Conference on Engineering Education

About Campus

ASTM Special Technical Publication

Engineering Studies

Studia Psychologica

Journal of Cognitive Engineering and Decision Making

2011 International Conference on Computer Science and Education, CSE 2011

2014 IEEE Frontiers in Education Conference (FIE) Proceedings 


\section{Continued}

Computational and soft skills development through the project based learning

International Conference on Computational Science

2003

Concept For An Interdisciplinary Seminar Added Value By Multiformity And Bridging The Gap Of Engineering And Humanities At The Rwth

EDULEARN13 Proceedings

Aachen University

Contribution of Shell Eco-Marathon engineering design experience to soft skills development: A qualitative analysis in the Asian context

Interactive Collaborative Learning

Control System Approaches For Sustainable Development And Instability Management In The Globalization Age

IFAC Proceedings Volumes

Controlled experiments as means to teach soft skills in software engineering

Overcoming Challenges in Software Engineering

Education: Delivering Non-Technical Knowledge and

Skills: Delivering Non-Technical Knowledge and 2014

Converging technologies in higher education-Paradigm for the "new" liberal arts?

Skills

Annals of the New York Academy of Sciences

Cooperative learning and soft skills training in an IT course

Journal of Information Technology Education

Course on engineering leadership

Journal of Professional Issues in Engineering

Education and Practice

Cultivating engineers' humanity: Fostering cosmopolitanism in a Technical University

International Journal of Educational Development

Curriculum development for project-based engineering education: How to include soft skills

Curriculum for an Engineering Renaissance

Degrees failing to boost students' "soft skills".

Demystifying Engineering.

Derive Hard Numbers From Soft Skills.

Designing the Liberally Educated Engineer.

Designing the module "methods for activating engineering creativity" on basis of competence approach

Determinants of Cognitive Skills and Competencies: Preliminary Statistical Analysis of PIAAC Data

Developing Competences in Engineering Students. The Case of Project Management Course

Developing construction professionals of the 21st century: Renewed vision for leadership

Developing students' collaborative skills in interdisciplinary learning environments

Developing technical competency and enhancing the soft skills of undergraduate mechanical engineering students through service-learning

Developing well-rounded graduates through integration of soft skills in the teaching of engineering courses

Proceedings SEFI and IGIP Joint Annual Conference

IEEE Transactions on Education

Times Higher Education

Diverse: Issues in Higher Education

TD: Talent Development

Peer Review

Recent Patents on Computer Science

VOPROSY OBRAZOVANIYA-EDUCATIONAL STUDIES

Procedia-Social and Behavioral Sciences

Journal Of Professional Issues In Engineering

Education And Practice

International Journal of Engineering Education

age

2014 IEEE Frontiers in Education Conference (FIE)

Proceedings.

Proceedings Of The 9th Conference On

Personality-Adapted Education System With Networking of Views and Activities)

Man-Machine-Environment System Engineering 


\section{Continued}

Educating Engineers in the art, science and practice of Project Management: A New Course

Educating the Humanitarian Engineer

Education or Creativity: What Matters Most for Economic Performance?

Effective Teaching.

El impacto del desarrollo de habilidades para la competitividad: Evidencia empírica de una comparación entre países

E-Learnings For Soft Skills In Technical Universities

Emotional and affective temperament in 23 professional areas

Emotions and interpersonal skills for IT professionals: An exploratory study

Employer Perspectives on the Role of Soft Skills in Subsidized Employment Relationships.

Enabling and characterizing twenty-first century skills in new product development teams

Engineering and Technology Board appoints new Chief Executive.

Engineering and the Liberal Arts: Strangers No Longer.

Engineering as a liberal education for the 21 st century

Engineering education in the Middle East and North Africa: An industry perspective

Engineering education the future is sharpening up, not dumbing down.

Engineering ethics-A collaboration between engineering and philosophy

Engineering Ethics Beyond Engineers' Ethics

Engineering Ethics Education and Moral Education Reform in Universities of Science and Engineering

Engineering ethics education on the basis of continuous education to improve communication ability

Engineering soft skills development to avoid hard knocks

Engineering student learning and emotional competencies

Engineering Students' Perceptions of Soft Skills, Industry Expectations, and Career Aspirations.

Engineering teaching behaviors in PK-3 classrooms.

Engineering Undergraduates' Perceptions of Soft Skills: Relations with Self-Efficacy and Learning Styles

Engineering with liberal and technical education (ELITE)

Engineers as Problem-Solving Leaders: Embracing the Humanities.
2008 IEEE International Conference On

Management Of Innovation And Technology,

Vols 1-3

Science and Engineering Ethics

2008

Economic Geography

Journal of Engineering Education

2012

El internacionalismo moderno

2006

Conference proceedings of» eLearning and Software

for Education

Journal of Affective Disorders

International Journal of Technology Enhanced Learning

Families in Society

International Journal of Engineering Education

Insight: Non-Destructive Testing \& Condition Monitoring

The Chronicle of Higher Education

Technical Paper-Society of Manufacturing

Engineers. AD

Advances in Engineering Education in the Middle East and North Africa

Engineers Journal

ASEE 2004 Annual Conference and Exposition, "Engineering Researchs New Heights"

Science and Engineering Ethics

Proceedings Of The 2015 3d International

Conference On Advanced Information And

Communication Technology For Education

Electrical Engineering in Japan

2011 IEEE Global Engineering Education Conference

2010 IEEE Transforming Engineering Education: Creating Interdisciplinary Skills for Complex Global Environments

Education and Practice 


\section{Continued}

Engineers learn "soft skills the hard way": Planting a seed of leadership in engineering classes

Engineers of tomorrow and beyond knowledge, insight and skills needed to work across borders

\section{Engineers take hard look at soft skills.}

Enhancement and assessment of engineering soft skills in a game-based learning environment

Enhancing individual employability: The perspective of engineering graduates

Enhancing Your Soft Skills.

Ergonomics service learning project: Implementing an alternative educational method in an industrial engineering undergraduate ergonomics course

Ethical Decision Making in the Conduct of Research: Role of Individual, Contextual and Organizational Factors: Commentary on \&quot;Science, Human Nature, and a New Paradigm for Ethics Education\&quot;

Ethical learning in higher education: The experience of the Technical University of Valencia

Ethics and IT: Module suggestion for a future degree qualification in Computing Engineering

Ethics as Philosophical History for Engineers

Ethics, engineers and drama

Ethics, social capital and development in engineering education: A pedagogical proposal

Evaluating the Soft Skills Performed by Applicants of Malaysian Engineers

Expectations and deficiencies in soft skills

Exploration on Infiltrating Human Education in the Basic Chemistry Courses of Science and Engineering

Extended student quality improvement programs of Xiamen University

Faculty development in engineering colleges in mainland China: The humanities perspective

Feedback on professional skills as enculturation into communities of practice

Flexible firms, skills and employment

For Better or Worse? The Marriage of Key Skills Development and On-line Learning.

For Illinois superintendent, the soft skills count.

Global and Competition-based Model for Fostering Technical and Soft Skills in Software Engineering Education

Global Engineers: Creating Needed Solutions Through Intercultural Competence

Global talent, local careers: Circular migration of top Indian engineers and professionals

Globalization, curricula reform and the consequences for engineers working in an international company.

Going Soft.
Electronic Engineering Times

2000

ECGBL2015-9th European Conference on Games Based Learning: ECGBL2015

Education + Training

Journal of Management in Engineering

1999

Human Factors and Ergonomics in Manufacturing \&

Service Industries

Science and Engineering Ethics

2012

European Journal of Engineering Education

2009

5th Iberian Conference on Information Systems and

Technologies.

Ethics in Science, Technology and Engineering

Science and Engineering Ethics

Revista de la Facultad de Ingenieria

2012

Procedia-Social and Behavioral Sciences

Global Engineering Education Conference

Mechanical Engineering And Green Manufacturing Ii, Pts 1 And 1

Annual International Conference of the IEEE Engineering in Medicine and Biology Society

1st IEEE International Conference on Teaching, Assessment, and Learning for Engineering, TALE 2012

Journal of Engineering Education

MPT Metallurgical Plant and Technology

International

1996

Journal of Vocational Education \& Training

American School Board Journal

2009 22nd Conference on Software Engineering Education and Training 


\section{Continued}

Group Work: A Humanistic and Skills Building Approach.

Social Work Education

Guidance for the Model Developer on Representing Human Behavior in Egress Models

Hard Core vs. Soft Core: A Debate

Help Wanted: “T-Shaped” Skills to Meet 21st Century Needs.

Higher education hones in on the skills gap.

How experiential service-learning affects student perceptions of education in their careers and as a wildlife management activity.

Human performance data in a high workload environment during the simulated Mars expedition \&quot; AustroMars\&quot;

Human skills are always needed.

Human-centred design in engineering curricula

Humanistic Quality Education in Engineering Undergraduate Education

Humanities and social sciences in engineering education-Postwar to postmodern and beyond

Humanities and social sciences on the outer in Australian engineering curricula

Humanities and social sciences within Civil Engineering curriculum

Humanities for Undergraduate Engineers: A Rich Paradox

Hutchinson Technology revamps employee training

ICCSE Invited Lecture: Importance of Development of Soft Skills in Engineering Education.

IChemE recruits soft skills course directors.

Ideas for adding soft skills education to service learning and capstone courses for computer science students

IDEAS: Interdisciplinary Design Engineering and Service.

Identification of non-technical skills from the resilience engineering perspective: A case study of an electricity distributor

Impact of a multimedia laboratory manual: Investigating the influence of student learning styles on laboratory preparation and performance over one semester

Implementing technology education in Finnish general education schools: studying the cross-curricular theme "Human being and technology"

Importance of Soft skills development in 21st century Curriculum.

Improving engineering students' communication competence:

Designing innovative learning strategies

Improving Students' Soft Skills through a NSF-Supported.

Improving undergraduate soft skills using m-learning and serious games

Incorporating ABET "soft skills" into energy conversion courses

Incorporating and assessing ABET "soft skills" in the technical curriculum

Incorporating Global Components into Ethics Education
Fire Technology

American Society for Engineering Education

$\mathrm{T}+\mathrm{D}$

$\mathrm{T}+\mathrm{D}$

Wildlife Society Bulletin

2012

2009

Acta Astronautica

2010

Farmers Weekly

2004

International Journal of Engineering Education

ASIA-PACIFIC MANAGEMENT AND

ENGINEERING CONFERENCE (APME 2014)

Technology and Society

2001

age

118th ASEE Annual Conference and Exposition

Journal of Engineering Education

1993

Journal Of Applied Manufacturing Systems

World Congress on Engineering 2009 (Volume 1)

TCE: The Chemical Engineer

2011

Proceedings of the 42nd ACM technical symposium on Computer science education

International Journal for Service Learning in Engineering

Safety Science

Education for Chemical Engineers

International Journal of Technology and Design Education

International Journal of Education \& Allied Sciences

International Journal of Engineering Education

Proceedings of the ASEE Annual Conference \& Exposition

Teaching, Assessment, and Learning for Engineering

2015

age

ASEE Annual Conference and Exposition, Conference Proceedings

Science and Engineering Ethics 


\section{Continued}

Incorporating social issues of computing in a small, liberal arts college: A case study

Increasing Student Engagement Through the Development of Interdisciplinary Courses: Linking Engineering and Technology, the Sciences, and the Humanities

Innovation and skills from a sectoral perspective: A linked employer-employee analysis

Innovative Recruiting-Targeting Passive Professionals.

Inspire, Connect, Persuade: Mix Technology And Art In Teaching Presentation Skills

Inspiring creativity for the Engineer of 2020

Integrated project: An innovative way to reduce students' burden and enhance soft skills and integration elements

Integrating Communication and Engineering Education: A Look at Curricula, Courses, and Support Systems.

Integrating engineering design with humanities, sciences and social sciences using integrative learning blocks

Integrating ethics into engineering education

Integrating humanities and liberal arts in engineering curriculum: Need, experiences and new directions

Integrating Service, Learning, and Professional Practice: Toward the Vision for Civil Engineering in 2025

Integrating soft skills in a BME curriculum

Integrating soft skills in the teaching of hard sciences at a private university: A preliminary study

Integration of green soft skills in Malaysian technical education

Integration Of Humanities And Social Sciences Into Civil Engineering Education

Integration Of Science, Technology, And Society (Sts) Courses Into The Engineering Curriculum

Integrative Learning: Integrating a Course on Human Values with Technology Education

Introducing professionalism and ethics in engineering curriculum

Introducing Survival Ethics into Engineering Education and Practice

\section{Is there a case for a "liberal education"?}

It ain't what you do, it's the way that you do it.

It's just so darn hard ...

Just another Title? MSc. Human Factors Engineering Versus Sports Engineering

Keep development skills current.

Learning leadership skills in a simulated business environment 42nd ACM Technical Symposium on Computer

Science Education, SIGCSE 2011

Frontiers in Education Conference

Economics of Innovation and New Technology

Power Engineering

Quality And Efficiency In E-Learning, Vol 1

Interdisciplinary Engineering Design Education Conference

Proceedings of the 8th WSEAS International Conference on Engineering Education

Journal of Engineering Education

2001 ASEE Annual Conference and Exposition:

Peppers, Papers, Pueblos and Professors

Contemporary Ethical Issues in Engineering

Pertanika Journal of Social Science and Humanities

Journal of Professional Issues in Engineering

Education and Practice

ASEE 2004 Annual Conference \& Exposition

Pertanika Journal of Social Sciences \& Humanities

Advanced Science Letters

2010 ASEE Annual Conference \& Exposition

American Society for Engineering Education

2010 IEEE International Conference On Technology Enhanced Education (ICTEE 2012)

Journal of Professional Issues in Engineering

Education and Practice

Science and Engineering Ethics

On the Horizon

Professional Engineering

IEEE Control Systems

Procedia Engineering

Electronic Engineering Times

Frontiers in Education Conference 


\section{Continued}

Liberal education for the engineer of 2020: Are administrators on board?

Liberal studies in engineering-a design plan

Liberal Studies in Engineering Programs-Creating Space for Emergent \& Individualized Pathways to Success for Women in Computing Disciplines.

Linking engineering and medicine: Fostering collaboration skills in interdisciplinary teams

Making Best Use of Alumni Associations for Holistic Development of Engineering Institutes

Making Choices: Ethical Decisions in a Global Context

Managing technical people: Creatively teaching the skills of human interaction in today's diverse classrooms

Manufacturing education and research at Texas A\&amp;M University: Responding to global trends

Mapping competencies

Meyerhoff scholars program: A strengths-based, institution-wide approach to increasing diversity in science, technology, engineering, and mathematics

Mind the gap: school leaver aspirations and delayed pathways to further and higher education.

Mine of the year 2020: technology and human resources

Mobile learning in art museum-the immersive teaching on arts and humanities

More Education and Employment Trends.

Moshe Barak, Michael Hacker (eds.): Fostering human development through engineering and technology education: ishers, Rotterdam, 2011, ISBN: 978-94-6091-547-5 (paperback)

Motivating an engineer to be a leader.

NASA's educational programs

Next generation science standards: Preparing students for careers in energy-related fields

Nontechnical Subjects In The German Engineering Curriculum-A Historical Overview

Nontechnical subjects in the German engineering curriculum: A historical overview

Note to Self: Save Humanity (A Social and Cultural History of the "Grand Challenges")

\section{On "Bettering humanity" in science and engineering education}

On B.S.E and B.S.ET for the engineering profession

Opening Engineering Students' Minds to Ideas Beyond Technology.

Organizational structure on the resilience of production processes based on human factors in the chemical industry

Panel-Ethics in modern universities of technology Challenges of the 21st century
2010 ASEE Annual Conference and Exposition

Engineering Studies

Proceedings of the ASEE Annual Conference \&

Exposition

IEEE Pulse

2012 IEEE International Conference On Engineering Education: Innovative Practices And Future Trends (AICERA)

Science and Engineering Ethics

Software Engineering Education and Training

Journal of Manufacturing Systems

Mechanical Engineering

Mount Sinai Journal of Medicine: A Journal of Translational and Personalized Medicine

Journal of Education \& Work

CIM bulletin

2013 IEEE 13th International Conference on Advanced Learning Technologies, ICALT 2013

Power

International Journal of Technology and Design Education

Engineering Studies

Government Information Quarterly

The Leading Edge

Technology in Society

Technology in Society

American Society for Engineering Education

Science and Engineering Ethics

Journal of Engineering Technology

IEEE Technology \& Society Magazine

Journal of the Institute

2014 IEEE International Symposium On Ethics In Science, Technology And Engineering 


\section{Continued}

Paul Revere in the science lab: Integrating humanities and engineering pedagogies to develop skills in contextual understanding and self-directed learning

Peer assessment of soft skills and hard skills

Personnel planning in Concurrent Engineering: A case study

Placement opportunities for human factors engineering and ergonomics professionals in industry, government/military and consulting positions

Practicing and evaluating soft skills in IT capstone projects

Practicing soft skills in software engineering: A project-based didactical approach

Preparing Engineering Graduates for the Real-World: The Butler University and Indiana-University Purdue-University Indianapolis Joint Engineering Dual Degree Program

Preparing graduate students to be HSE professionals

Preparing Next Generation of Software Engineers for Future Societal Challenges and Opportunities

Product design and innovation: a new curriculum combining the humanities and engineering

Product realization for Global Opportunities: Learning collaborative design in an international setting

Prof says skills gap is a cash problem.

Professional development of Russian HEIs' management and faculty in CDIO standards application

Professional development strategies: beyond the classroom

Professional skills in international multidisciplinary teams

Project Approach in Humanities as a Cognitive Strategy of Modern Engineering Education

Project management education: The human skills imperative

Promoting "soft skills" from the start of the engineering degree and the case study of the special "Projeto FEUP" course

Questioning a tradition: a French way of excellence.

Reconstructing engineering from practice

Reducing the risk of failure by better training and education

Relevance of further education and training college engineering learning programmes within the apprenticeship context

Requirements upon human competencies in globally distributed manufacturing

Revisiting a liberal activity in a college of engineering engineers as poets 10 years later

Role of soft skills in engineering education: Students' perceptions and feedback

Science, Technology and Values: Promoting Ethics and Social Responsibility 114th Annual ASEE Conference and Exposition, 20072007

Journal of Information Technology Education

Human Factors and Ergonomics in Manufacturing \&

Service Industries

Proceedings Of The Human Factors And Ergonomics Society 43rd Annual Meeting, Vols 1 And 2

Proceedings of the 16th Annual Conference on Information Technology Education

Overcoming Challenges in Software Engineering Education: Delivering Non-Technical Knowledge and 2014 Skills

2011 ASEE Annual Conference \& Exposition

Safety Science

7TH International Workshop On Social Software Engineering (SSE 2015)

Frontiers in Education Conference

1999

International Journal of Engineering Education

Industrial Engineer: IE

European Journal of Engineering Education

Network Computing

International Journal of Engineering Education

Procedia-Social and Behavioral Sciences

International Journal of Project Management

International Journal of Engineering Education

European Journal of Engineering Education

Engineering Studies

Engineering Failure Analysis

Mediterranean Journal of Social Sciences

Computers in Industry

American Society for Engineering Education

Enhancing Learning and Teaching Through Student Feedback in Engineering

IFAC Proceedings Volumes 


\section{Continued}

Searching for a new engineer

Should Engineering Ethics be Taught?

Social aspects of web 2.0 technologies: Teaching or teachers' challenges?

Social Competences and personal ethical development-Soft Skills or a need for survival?

Social Constraints: A Critical Component of Global Humanitarian-based Projects

Socially Humanistic Technocrats: Bringing Sensitivity to Workplace

Soft Skill Development via Chem-E-Car Project

Soft skills for the new economy: Their place in graduate education in engineering and engineering technology

\section{Soft skills in engineering education: A practical experience in an} undergraduate course

Soft skills in higher education: importance and improvement ratings as a function of individual differences and academic performance.

Soft Skills in the Technology Education Classroom: What Do Students Need?

\section{Soft-Skill Prescription}

Standards-based assessment of Humanities/Social Science (H/SS) programs in the liberal education division (LED)

Strengthening competency linkage to innovation at Korean universities

Strengthening human resources for new and renewable energy technologies of the 21 st century-UNESCO engineering education and training programme

STS for engineers: Integrating engineering, humanities and social sciences

Students In Engineering And Humanities In Poland-The Differences In

Learning And Professional Strategies

Successful Science and Engineering Teaching in Colleges and Universities.

Tale of two programs: Integrating humanities and engineering

Teaching "soft" skills in Software Engineering

Teaching and developing social and emotional skills with technology

Teaching competences in control education: the French industrial science example

Teaching creativity, team work and other soft skills for entrepreneurship

Teaching engineering design with humanities and social sciences companion courses

Teaching Ethics to Engineers: Ethical Decision Making Parallels the Engineering Design Process

Teaching Human-Centered Design Innovation across Engineering, Humanities and Social Sciences

Teaching manufacturing engineers how to optimize technical and personnel systems: Closing the competency gaps in manufacturing education

Teaching "soft" skills to engineers
2000 ASEE Annual Conference and Exposition:

Engineering Education Beyond the Millenium

Science and Engineering Ethics

Procedia-Social and Behavioral Sciences

Technology and Society

2013 ASEE Annual Conference

Procedia-Social and Behavioral Sciences

Procedia-Social and Behavioral Sciences

Proceedings of the 2007 American Society for Engineering Education Annual Conference \& Exposition.

Interactive Collaborative Learning

Educational Psychology

Technology Teacher

2008

Mechanical Engineering

2001 ASEE Annual Conference and Exposition:

Peppers, Papers, Pueblos and Professors

Scientometrics

Renewable Energy

Proceedings of the 1997 ASEE Annual Conference

ICERI2011 Proceedings

Journal of Chemical Education

2006

Proceedings of the 1997 ASEE Annual Conference

2011 IEEE Global Engineering Education Conference 2011

ACM Transactions on Computer-Human Interaction (TOCHI

IFAC Proceedings Volumes 2013

Journal of Entrepreneurship Education

Proceedings of the 1995 25th Annual Conference on Frontiers in Education. Part 1 (of 2)

Science and Engineering Ethics

International Journal of Engineering Education

Technical Papers-Society Of Manufacturing Engineers-All Series-

International Journal of Electrical Engineering Education

\section{(1)}

0

3

012

5

0




\section{Continued}

Teaching the 3 "Co's" in the engineering classroom

Teaching virtue: Pedagogical implications of moral psychology

Technical skills aren't enough for engineers.

Technologies, humanities and paradigms of the science. Configurations of new strategies in research and teaching

The allocation to the study of humanities and social sciences at Australian engineering education

The Challenge Of Educating Ux Professionals-How To Tailor To Coorporate Needs

The Development and Integration of Humanitarian Engineering Curriculum in an Engineering Technology Program

The development of skills in the ICT sector: Analysis of engineering students' perceptions about transversal skills

The development of the competencies linked to the human dimension of engineering

The European Project Semester at ISEP: the challenge of educating global engineers

The evaluation of the research on the arts and humanities in Turkey: A scientometric approach

The Fifth Column: Using Operations Research to Model a Way to (Successfully!) Teach Humanities to Engineers and Scientists in Such a Way Interfaces as to Inspire Cultural Breadth and Lifelong Learning

The forming humanistic in engineering education

The good engineer: Giving virtue its due in engineering ethics

The holism in competence-A study on building wholesome competence in people

\section{The Humanities and Their Effect On Engineering Education}

The impact of students' skills and experiences on empirical results: A controlled experiment with undergraduate and graduate students

The language of youth

The liberal art of engineering-a compelling narrative.

The management of youth employment in a lifelong engineering education system

The need for alternative paradigms in science and engineering education.

The need for creative skills in design engineering, and how education can develop them

The networking company antecedents for coping with relationships and networks effectively

The new alliance between engineering and humanities educators

The philosophical technologies

The place of soft skills in the development of hard sciences: The Malaysian higher education scenario

The problem of knowledge in incorporating humanitarian ethics in engineering education: Barriers and opportunities age

Science and Engineering Ethics 2010

Electronic Engineering Times

3rd International Conference Of Education, Research And Innovation (ICERI2010)

Joint International IGIP-SEFI Annual Conference 2010

2010

ICERI2014: 7TH International Conference Of Education, Research And Innovation

age

International Journal of Engineering Education

age

European Journal of Engineering Education

Energy Education Science And Technology Part B-Social And Educational Studies

1999 ASEE Annual Conference and Exposition: Engineering Education to Serve the World

Science and Engineering Ethics

Systems Conference (SysCon)

2016

IEEE Communications Magazine

Proceedings of the 19th International Conference on Evaluation and Assessment in Software Engineering

Industrial Engineer: IE

Engineering Studies

International Review of Management and Marketing

European Journal of Engineering Education

Information, Intelligence, Systems and Applications (IISA), 2015 6th International Conference on. IEEE

Industrial Marketing Management

Global J. of Engng. Educ

Technology in Society

International Journal of Humanities

Proceedings. Frontiers in Education. 36th Annual Conference.

\section{0}

8

10

4

4

4




\section{Continued}

The recognition of and increasing value of professional engineering skills

The role of humanities education in the training of engineers

The Role Of Robinsonian Skills In Successful Blended Learning For Engineering Students

The skills deficit myth: The securing of engineering and science skills in Germany requires a strategic re-orientation in industrial training portfolios

The use of employer surveys to evaluate professional-practice related skills in an industrial experience program

Thinking About the Mathematics Education of Humanities in University of Science and Engineering

To be or not to be successful? That does not only depend on technology, but also on human factors

To see the world anew: learning engineering through a humanistic lens

Towards equilibrium engineering

Transcultural and transdisciplinar competences. Technological transformations of society and education

Transforming Online Humanities Education: The H-OEH Network.

Transforming STEM to STEAM (Work in Progress): How a Traditionally Run STEM Camp Succesfully Incorporated the Arts into Its Framework

Truth and Method: Humanities Scholarship as a Science of Exceptions

Turkish and north American engineering programs: A comparative study of curricular emphases on mathematics, basic sciences, humanities, and social sciences

Turnover of highly educated R\&D professionals: The role of pre-entry cognitive style, work values and career orientation.

Underpinning a land management approach to surveying education

Understanding Ill-Structured Engineering Ethics Problems Through a

Collaborative Learning and Argument Visualization Approach

Upgrading translational engineering in medicine and biology through conscious-technology with humanistic motivation and global vision

User centered design of human factors class projects

Using the Contextual Skills Matrix for PBL Assessment

Using the perceptions of chemical engineering students and graduates to develop employability skills

We don't know or DO WE?

What is engineering management? A new look at an old question

What is missing for traditional design-centric engineering education to better prepare newly graduated engineers for the global era?

When science should be a humanity.

When to avoid approaching.

Which Professors are Helping Universities to Transfer Technology by Creating Spin off? age

2004

Russian Education And Society

Quality And Efficiency In E-Learning, Vol 1

International Journal of Human Resources

Development and Management

age

2003

Proceedings Of The Fifth International

Symposium-Education Management And

Knowledge Innovation Engineering

Journal of Cases on Information Technology

Engineering Studies

2015

Technology and Society

1997

ICERI2010 Proceedings

Distance Education Report

2016 IEEE Integrated STEM Education Conference

Interdisciplinary Science Reviews

IEEE Transactions on Education

1998

Journal of Occupational \& Organizational Psychology

Surveying and Land Information Systems

Science and Engineering Ethics

Health And Technology

Proceedings of the Human Factors and Ergonomics Society Annual Meeting

International Journal of Engineering Education

1998

Education for Chemical Engineers

2016

Engineering Management

2004

Engineering Management Journal

International Journal of Engineering Education

New Scientist

1991

Journal of Sport \& Exercise Psychology

1998

Proceedings Of The 10th European Conference On Innovation And Entrepreneurship (ECIE 2015) 


\section{Continued}

Work in Progress-e-TAT: Online Tool for Teamwork and "Soft Skills" Assessment in Software Engineering Education

Work in progress-Soft skills within a project-Based approach: A multimedia engineering degree

The Globally Competent Engineer: Working Effectively with People Who Define Problems Differently

Experiential Learning Environments: Do They Prepare Our Students to be Self-Directed, Life-Long Learners?

The Human Face of Engineering

Ethics Teaching in Undergraduate Engineering Education

Looking Beyond Content: Skill Development for Engineer

Engaging and Supporting Problem Solving in Engineering Ethics

The Socially Responsible Engineer: Assessing Student Attitudes of Roles and Responsibilities

Fostering Argumentation While Solving Engineering Ethics Problems

Teaching Creativity in Engineering Courses
2009 IEEE Frontiers in Education Conference

2010

2010 IEEE Frontiers in Education Conference

2010

JEE

2006

JEE

2006

JEE

2008

JEE

2008

JEE

2008

JEE

2009

JEE

2011

JEE

2011

JEE 